\title{
REINALDO CATALÁN Y FRANCISCO OYARZÚN, BAQUEANOS DEL SUR \\ DE TIERRA DEL FUEGO (CHILE) Y SU PARTICIPACIÓN EN EL ORIGEN DE LA SENDA DE PENETRACIÓN VICUÑA-YENDEGAIA
}

SAMUEL GARCÍA O.*

\author{
El hombre es el único animal que deja más \\ huellas que las de los pies \\ Nicolas Mihovilovic
}

\section{RESUMEN}

Han pasado 33 años desde que dos baqueanos fueron los responsables del éxito de la expedición encomendada a Hans Niemeyer Fernández (1921-2005), cuyo objetivo era analizar la factibilidad técnica de la construcción de un camino al sur de Tierra del Fuego (Chile). A lo largo de este documento se entregan no tan sólo antecedentes fotográficos y escritos inéditos de esta expedición, poco conocida, realizada entre los meses de febrero y marzo de 1978, sino que también, información sobre la vida de los baqueanos a los cuales se debió su éxito. El fruto de esta travesía es la actual construcción de la senda de penetración Vicuña - Yendegaia cuyo fin es conectar a la Isla Grande de Tierra del Fuego en toda su longitud a través de una vía terrestre.

PALABRAS CLAVE: Tierra del Fuego, baqueano, senda de penetración Vicuña-Yendegaia, territorio marginal.

\section{REINALDO CATALÁN AND FRANCISCO OYARZÚN, BAQUEANOS FROM THE SOUTH OF TIERRA DEL FUEGO (CHILE) AND THEIR ROLE IN THE ORIGIN OF THE PENETRATION PATH TO VICUÑA - YENDEGAIA}

\begin{abstract}
33 years have passed since two baqueanos where the responsible men of the successful expedition entrusted to Hans Niemeyer Fernández (1921-2005), whose aim was to analyze the technical feasibility for constructing a road in the south of Tierra del Fuego (Chile). Throughout this document not only, photographic precedents and unpublished writings of this little-known expedition, made between the months of February and March 1978, are delivered, but also information about the life of the baqueanos who
\end{abstract}


were the responsible of its success. The fruit of this voyage is the current construction of the penetration path Vicuña - Yendegaia whose aim is to connect Tierra del Fuego in all its overland extent.

KEY WORDS: Tierra del Fuego, baqueano, penetration path Vicuña-Yendegaia, marginal territory.

\section{INTRODUCCIÓN}

En octubre del 2010 visitó la Escuela de Arquitectura de la Universidad de Magallanes (Punta Arenas) el arquitecto Juan Baixas, director de la Escuela de Arquitectura de la Universidad Católica de Chile. En esa ocasión sostuvimos una conversación sobre el sur de Tierra del Fuego y me comentó que Hans Niemeyer, un reconocido arqueólogo chileno, había realizado años atrás una expedición en aquella zona y que posiblemente pudo haber plasmado en un escrito dicha experiencia, algo muy común en él. Buscamos inmediatamente en internet y dimos con la cita bibliográfica, efectivamente existía aquel artículo y se publicó en una revista llamada Expedición a Chile en 1978.

En enero del 2011, con el artículo de Hans Niemeyer en mano, visité el lago Fagnano ${ }^{1}$ (Tierra del Fuego, Chile), allí pude conversar con Germán Genskowsky Middleton (1945), único vecino del solitario lago Fagnano. Le pregunté algunas cosas relacionadas con la historia del lugar y sobre la expedición de Hans Niemeyer y me dijo: ... Si quieres conocer la historia de esta zona, primero tienes que hablar con una persona, él se llama Reinaldo Catalán y le dicen "don Cata”. El vivió mucho tiempo acá, tiene un excelente memoria y se acuerda de todo, es un verdadero libro. Y en un tono melancólico prosiguió: el día en que "don Cata" parta de este mundo, no sólo partirá él, sino también toda un historia. El nombre de Don Cata me sonaba familiar ya que lo había leído en el artículo de Hans Niemeyer.

\section{EXPEDICIÓN VICUÑA-YENDEGAIA}

En enero de 1978 la Secretaría Regional de Obras Públicas de la XII Región le encomendó a la firma de ingenieros consultores Sergio Silva y Víctor Bogado el análisis de factibilidad técnica de

1 Lugar que constituyó el campamento $\mathrm{N}^{\circ} 5$ de la expedición de Hans Niemeyer en 1978. un camino que uniera la estancia Vicuña con bahía Yendegaia, en el tercio sur de la Isla Grande de Tierra del Fuego (Chile) (ver Fig. 47), se trataba de un camino de soberanía y de desarrollo turístico en una zona pletórica de bellezas naturales ${ }^{2}$, para tal efecto era necesario realizar una expedición, en un lugar despoblado y escasamente explorado, que uniera los dos puntos extremos del camino que solicitaba el mandante. Para que se hiciera cargo, como jefe, in situ de la expedición, la firma de ingenieros consultores eligió, por su vasta experiencia en expediciones geográficas y reconocimientos técnicos a lo largo del país ${ }^{3}$, al reconocido arqueólogo e ingeniero Hans Niemeyer Fernández. La expedición que se realizó entre el 25 de febrero y 15 de marzo de 1978 quedó registrada en el informe Proyecto de factibilidad técnica de un camino de estancia Vicuña a Yendegaia (MOP, 1978) ${ }^{4}$ y en el artículo Expedición de estancia Vicuña a Bahía Yendegaia en la Isla Grande de Tierra del Fuego (Niemeyer, 1978) ${ }^{5}$ publicado en la revista Expedición a Chile. Junto con Hans Niemeyer formaron parte del grupo expedicionario el constructor civil Eduardo Larravide Lynch, el suboficial de Ejército Luís Arata Campodónico, el funcionario administrativo de la Dirección General de Obras Públicas de Punta Arenas Arístides Vargas Morris (en calidad de maestro de cocina) y los baqueanos Francisco Oyarzún Díaz, Reinaldo Catalán Oporto y su ayudante Víctor Garay Bórquez.

Marcela Larravide Descouvieres, hija de Eduardo Larravide Lynch (1930-1998), quién formó

\footnotetext{
Niemeyer, $1978: 3$

MOP, $1978: 10$

4 Este informe se divide en dos partes, la primera, en la que se relata la expedición y la segunda que es más bien técnica en que se entregan características geográficas del área del proyecto, características técnicas del camino, estimación de costos etc. "El ingeniero Hans Niemeyer F., fue el encargado de preparar el presente informe" (MOP,1978:2)

5 Este artículo escrito por Niemeyer sólo relata la expedición, sin embargo la introducción de este artículo que se incluye en este documento, es reproducida parcialmente en MOP,
} 1978. 
parte del grupo expedicionario, conserva el ejemplar original sin editar del libro publicado por el MOP, este ejemplar contiene fotografías originales $e$ inéditas tomadas por su padre y que se incluyen en este documento. Curiosamente en este libro Eduardo Larravide adjuntó un recorte del diario La Prensa Austral del miércoles 16 de marzo de 1994 , el cual se refiere a que tres miembros de la Sociedad Chilena de Exploraciones habrían sido los primeros chilenos en unir Pampa Guanacos y bahía Yendegaia entre los días 1 y 12 de marzo de 1994. Uno de los miembros afirma ... sabíamos que era un trazado difícil que no había sido cubierto por ninguna expedición chilena.

\section{LOS BAQUEANOS PROTAGONISTAS}

El desarrollo de esta expedición permitió conocer a dos hombres, Reinaldo Catalán Oporto (1927) y Francisco Oyarzún Díaz (1934) que participaron como baqueanos y a los cuales se debió el éxito de la expedición encomendada a Hans Niemeyer. En un pasaje de su relato, Hans Niemeyer menciona de la siguiente manera a los baqueanos, primero a Reinaldo Catalán: [...] Su desinteresada colaboración fue decisiva para el éxito de la expedición, toda vez que con gran sacrificio después de terminada una jornada salía a pie en busca de la ruta a seguir al día siguiente. ${ }^{6}$ Y luego a Francisco Oyarzún: [...] A no ser por el baqueano, en algunas ocasiones se habrían tomado equivocadamente senderos de guanacos como la buena ruta ${ }^{7}$

Catalán y Oyarzún viven actualmente en la ciudad de Punta Arenas y el presente artículo es un homenaje a estos sacrificados y esforzados hombres que por más de 40 años habitaron y recorrieron el desolado, desconocido y soberbio sur de Tierra del Fuego (Chile).

Reinaldo Catalán: Un fueguino de alma

En la actualidad visitar el lago Deseado, trasponer el cordón La Paciencia y llegar al lago Fagnano no tiene mayores inconvenientes, por lo menos en verano, pero hace tan sólo 6 años, cuando

\footnotetext{
Ver Niemeyer en MOP (1978:11-12)

Ver Niemeyer, 1978:5
}

no existía accesibilidad vehicular, el panorama era muy distinto. Desde la localidad de estancia "Vicuña" hasta el lago Fagnano, lo que hoy en vehículo se recorre en menos de 2 horas, antes significaba entre 3 a 4 días de cabalgata por una huella llena de riesgos, conocida sólo por pocos baqueanos. "Vadear ríos", "buscar la picada por entre los montes", "se viene la cerrazón", "la bestia resbaló", eran frases cotidianas. Esto lo sabe muy bien Reinaldo Catalán Oporto que por más de 20 años realizó a caballo el trayecto de lago Fagnano a estancia Vicuña para posteriormente dirigirse a Porvenir. Sin embargo no lo hacía sólo sino que arreando sus vacunos que solían ser entre 18 a 42 animales con la colaboración de otro baqueano y la de sus perros, demorándose 21 días en el trayecto entre la ribera sur del lago Fagnano y Porvenir.

Don Cata, como se suele llamar en Tierra del Fuego a Reinaldo Catalán Oporto nació el 1 de junio de 1927 en Osorno y llegó a Punta Arenas en diciembre de 1953 a los 27 años de edad sin otro objetivo que la búsqueda de un trabajo bien remunerado para ayudar económicamente a su familia residente en aquella ciudad. En enero de 1954 se embarcó a Tierra del Fuego y sin estar dentro de sus intenciones, ya que iba en calidad de acompañante, se quedó trabajando en las inmediaciones del cabo Nose para Alfredo Agoni Solís (1904-1975). Desde aquí en adelante don Cata estuvo ligado a las faenas propias de los aserraderos y del cuidado de ganado, principalmente de vacuno. El 5 de enero de 1955, aún trabajando para Alfredo Agoni y siendo éste contratista de la firma Campos y Marcou, se dirigió por primera vez y por vía marítima a Caleta María ubicada en la bahía Azopardo, extremo oriental del seno Almirantazgo, para la faena de elaboración y posterior envío a Punta Arenas de 4000 vigas dejadas por el aserradero "Caleta María". Don Cata recuerda que en aquel tiempo Caleta María estaba habitada por alrededor de 40 personas siendo la mayoría gente trabajadora y esforzada proveniente de Chiloé además de su administrador Domingo Fernández quien residía allí junto a su familia. El aserradero de Caleta María (1942-1957) fue fundado por la firma Campos y Marcou conformada por Francisco Campos Menéndez (1905-1991) y Alejo Segundo Marcou (1887-1957), cuyas instalaciones y actividades significarían el desarrollo económico máximo que presentó el lugar en su historia. 
Terminada la faena en Caleta María, don Cata se trasladó al lago Fagnano donde se desempeñó hasta abril de 1956 como corredor o balsero de vigas, siendo éstas transportadas hasta Caleta María a través del río Azopardo ${ }^{8}$. El castor en aquel tiempo era un animal totalmente desconocido y respetado. Don Cata recuerda que se le asociaba a duendes que tenían sus casas sobre piscinas, hasta que llegó un estudioso y mostró un libro con animales, quienes habían visto al castor lo reconocieron inmediatamente en las páginas. Recién en ese momento supieron de que se trataba, pero existía incertidumbre si sería agresivo o no. Todo el temor y respeto que emanaba el castor terminó cuando se cazó al primer animal.

Don Cata, cansado de lo poco humano de su patrón, se retiró de Caleta María y encontró un nuevo puesto de trabajo en los aserraderos del poeta José Grimaldi (1911-1992) ubicados en el seno Otway. Pasado un año y debido a las promesas y buenas ofertas que recibe, vuelve a Tierra del Fuego para trabajar en el labrado y acarreo de vigas en el sector del río Cóndor y Puerto Arturo para la firma Baeriswyl por el lapso de un año, sintiéndose estafado por sus patrones $y$ sin recibir pago alguno retornó a los aserraderos de Grimaldi, quien lo recibió afectivamente, desempeñándose esta vez de palanquero. Don Cata recuerda al poeta Grimaldi como el mejor patrón que tuvo, una persona muy humana, cariñosa y comprensiva con sus trabajadores a quienes los llamaba "hijos". En 1960 volvió definitivamente a Tierra del Fuego, esta vez al lote 4 ubicado a $25 \mathrm{~km}$. al interior de Cameron. En febrero de 1966 se trasladó finalmente al sur del lago Fagnano para trabajar en la crianza de vacunos en los terrenos arrendados por Santiago Gómez Andrade (1901-1980), terrenos que a partir del 1 de abril de $1979^{9}$ tomó en arrendamiento hasta 1980 . Mientras permanece en el sur del lago Fagnano se convirtió en el único poblador de esta región y construyó dos ranchos, uno en las inmediaciones de la desembocadura del río Betbeder (Fig. 37) y otro a un $\mathrm{km}$. de distancia del limite fronterizo con Argentina.

8 La instalación de los aserraderos se prefería a orillas de los ríos, para facilitar la extracción de los troncos rollizos desde los montes, utilizando para ello el arrastre de las aguas para su transporte hasta el aserradero (Baeriswyl 2003:27)

9 Con fecha 1 de abril de 1979, Reinaldo Catalán se adjudica el Lote fiscal tipo c) del plano 3 ubicado en el seno Almirantazgo. Corporación Nacional Forestal, XII Región de Magallanes.
En 1966 el único habitante de Caleta María era Lucio Genskowsky Pietrogrande (1921-1977), quien subarrendaba los terrenos a la firma Campos y Marcou, y sus trabajadores que desarrollaban faenas madereras explotando los bosques de la cuenca occidental y norte del lago Fagnano, los cuales ante cualquier emergencia o eventualidad se comunicaban con don Cata a través de dos fogatas encendidas simultáneamente a orillas del lago Fagnano. Entre los trabajadores de Lucio Genskowsky estaba Francisco Oyarzún Díaz, baqueano que también participó en la expedición de Niemeyer en 1978.

\section{Francisco Oyarzún: Un peregrino de la Patagonia}

Oyarzún, nació el 1 de mayo de 1934 en la isla de Chiloé y llegó a Punta Arenas en 1949, a la edad de 15 años, para trabajar junto a su padre, quién se encontraba trabajando en la estancia "Laguna Blanca". Su largo peregrinaje por la Patagonia comenzó en su primer puesto de trabajo en la estancia "Laguna Blanca" donde ejerció de leñero junto a su padre. Desde entonces se desempeñó en los más variados oficios que ofrecía la Patagonia de antaño; leñador, peón, palanquero, palero, bagualero, carneador, carretero, baqueano, puestero, amansador, ovejero, alambrador, guachimán ${ }^{10}$, campañista ${ }^{11}$.

Durante un año trabajó en el hotel Cabeza del Mar desempeñándose de leñero y carneador de animales. En 1952, año en que falleció su padre, ya se encontraba trabajando de peón en la estancia "María" y su sección "Las Coles"12. En 1954 realizó el servicio militar por un período de dos meses en el Regimiento Pudeto en la ciudad de Punta Arenas. Finalizada su breve estadía militar se dirigió hacia Argentina donde trabajó como palero en la mina de carbón de Río Turbio, luego viajó a Río Gallegos donde consiguió emplearse como peón en la estancia "Librún", de Ernesto Lenzner, ubicada al norte de Cancha Carrera. Terminado su paso por el vecino país, Oyarzún regresó a Chile y logró obtener un puesto de trabajo en la localidad de Posesión donde permaneció por dos años desarrollando faenas de carga y descarga de materiales pertenecientes a ENAP.

Guachimán: versión criolla de "Watchman", el observador, cuidador

11 Campañista: Campero, encargado de vacunos y caballos.

12 Ambas ubicadas en la localidad de Río Verde. 
En 1965 Oyarzún se trasladó al sur de Tierra del Fuego entre la zona que comprende el lago Fagnano y Caleta María (seno Almirantazgo) donde trabajó en el balseo de vigas a través del río Azopardo para Lucio Genskowsky Pietrogrande a quien habría conocido en la estancia "Las Coles" en 1952. Entre 1965 y 1973 Oyarzún trabajó simultáneamente en los aserraderos de Genskowsky ubicados en Caleta María y Morro Chico y en el aserradero de Francisco Tarrío Fernández (1912-2001) ubicado en río Chico, isla Dawson.

Cuando Genskowsky se retiró de Caleta María en el año 1973, Oyarzún se trasladó con él a su aserradero ubicado en Morro Chico, comuna de Laguna Blanca, donde trabajó hasta el año de la trágica muerte de don Lucio ocurrida el 31 de enero de 1977 a sus 56 años de edad.

Al retirarse de Caleta María, Genskowsky vendió sus derechos de subarriendo a Arturo Barrientos

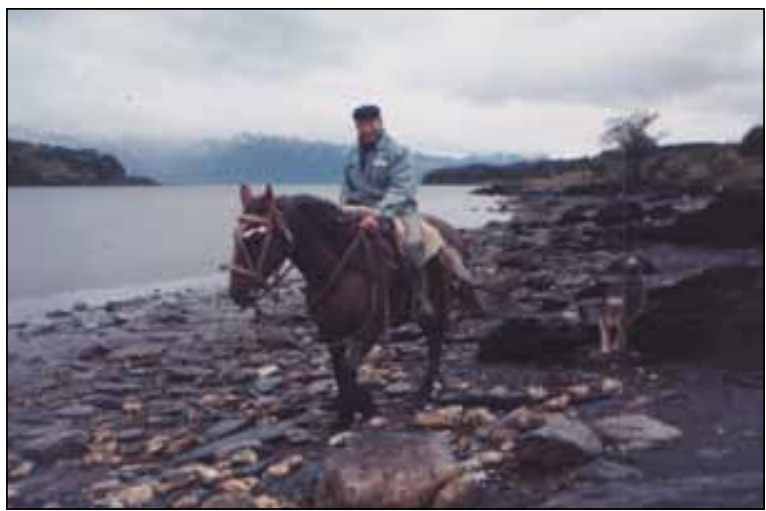

Fig. 1. Francisco Oyarzún en La Paciencia. (Foto gentileza de Francisco Oyarzún)

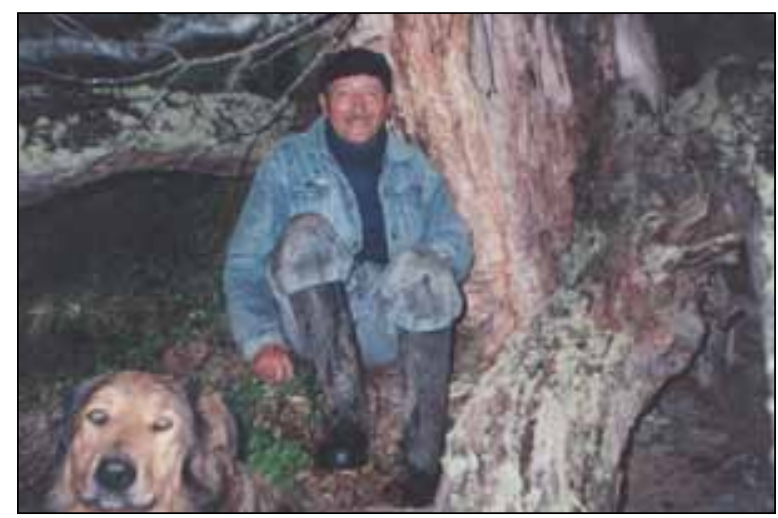

Fig. 3. Francisco Oyarzún junto a su perro Quirón,1990. (Foto gentileza de Francisco Oyarzún)
Leal (1908-1987), jubilado de Carabineros de Chile y oriundo de Osorno. En enero de 1978 Oyarzún retornó a Caleta María para trabajar por alrededor de una semana con Arturo Barrientos. Cumplido el trato, dejó Caleta María y se fue a trabajar para Santiago Gómez Andrade (1901-1980) al sur del lago Fagnano junto a Reinaldo Catalán a quien conocía desde 1966. Es por estas circunstancias que estos dos baqueanos se encontraban en la isla cuando se realizó la expedición Vicuña-Yendegaia en 1978.

\section{Una tierra abandonada}

En la década del 70 el sector que comprende el seno Almirantazgo - lago Fagnano ya no era el mismo de hace treinta años desde el punto de vista de la ocupación humana. Según Reinaldo Catalán Oporto en los años prósperos de producción entre el lago Fagnano y seno Almirantazgo trabajaban

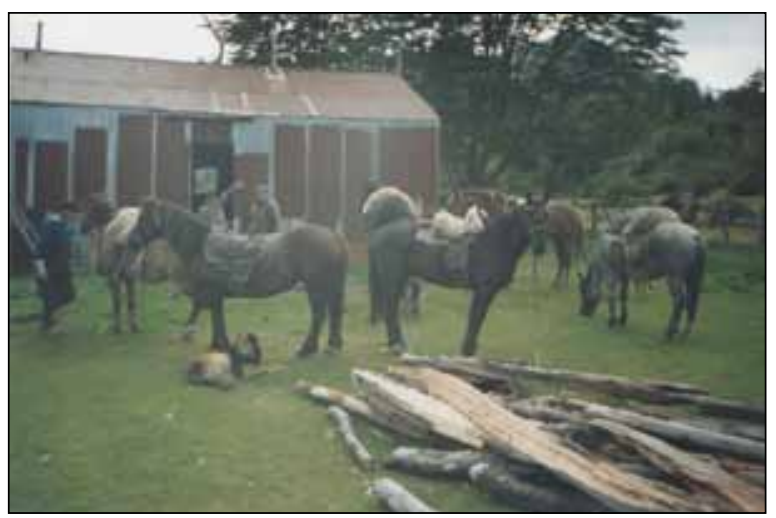

Fig. 2. Francisco Oyarzún (izq.) en La Paciencia. (Foto gentileza de Francisco Oyarzún)

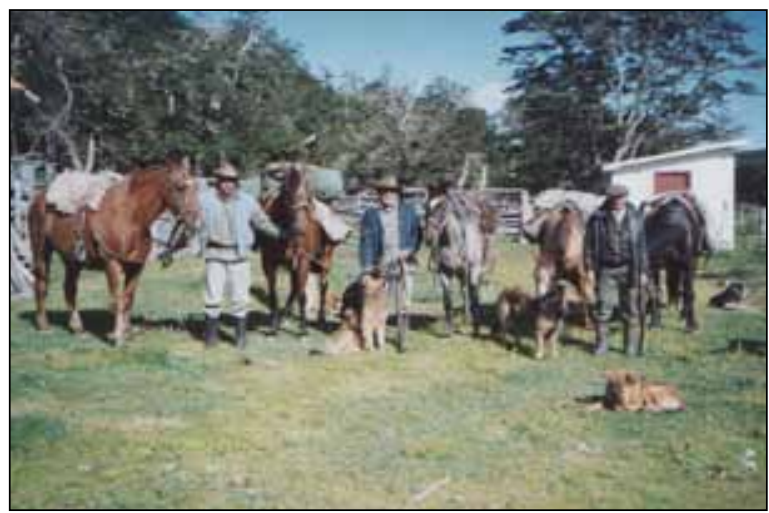

Fig. 4. Francisco Oyarzún (der.) preparando partida a la localidad de La Paciencia,1991.

(Foto gentileza de Francisco Oyarzún) 


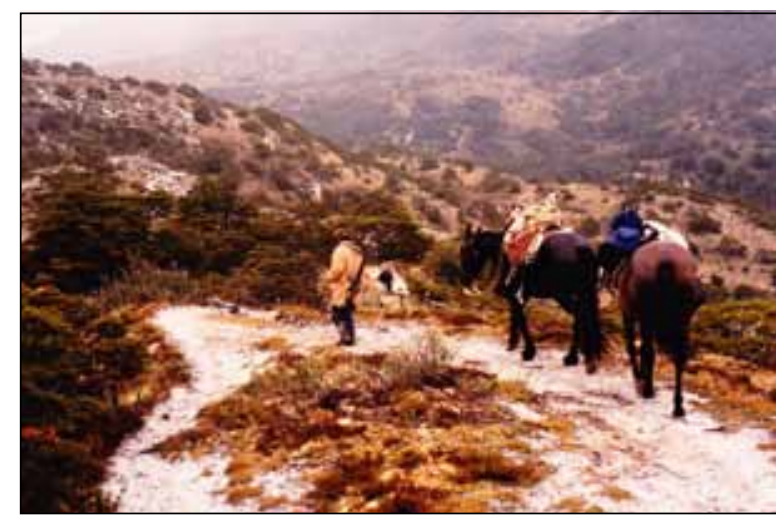

Fig. 5. Reinaldo Catalán guiando a una comisión a Caleta María,1987.(Foto gentileza de Reinaldo Catalán)

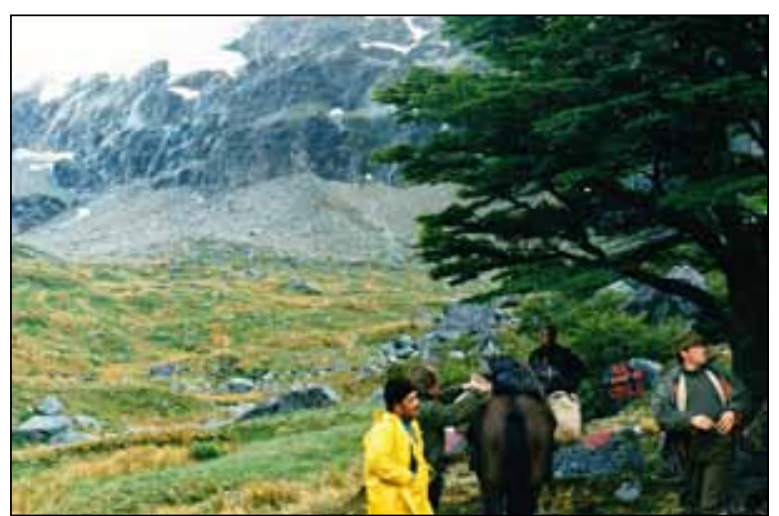

Fig. 6. Don Cata guiando a comisión militar en la inmediaciones del paso Las Lagunas, Cordillera

Darwin.(Foto gentileza de Reinaldo Catalán) aproximadamente 150 personas relacionadas con la industria maderera. Por esto, en la década del 70, el tercio sur de Tierra del Fuego, más que un territorio casi no hollado por el hombre era más bien un territorio abandonado por este, dado que el motivo principal para habitarlo, la explotación maderera, declinó producto de diversos factores..$^{13}$ De la original estancia "Isabel" fundada en 1918 por Pablo Dieter ${ }^{14}$ ya no quedaban vestigios de sus construcciones, un gran incendio había borrado todo signo. El valle Jackson, que había sido una importante vía terrestre en los tiempos de apogeo que comunicaba el lago Fagnano y el seno Almirantazgo era desconocida $y$ pocos son los rastros que quedan de la huella que comunicó al aserradero La Paciencia ${ }^{15}$ con la estancia "La Marina" (Argentina) ${ }^{16}$. De las obras

13 El más significativo fue la gran crisis (...) que afectaría y castigaría duramente a la economía y sociedad Magallánica durante el lapso 1946 y 1952. Ello acarreó la paralización definitiva de las factorías forestales de la costa del Seno Almirantazgo (Martinic, 2009:164.)

14 (Martinic,2009:123)

15 El aserradero La Paciencia fue iniciado por la firma Comercial Menéndez Behety en 1918 que inicia en este mismo año el aserradero de Puerto Arturo “(...) significando estos establecimientos fuertes inversiones en construcciones, maquinarias, equipos y hacienda vacuna, lanar y caballar". (Martinic, 2009:124)

16 ... este distrito de producción fundamentalmente forestal había tenido su periodo histórico de esplendor entre 1930 y 1945 y que los grandes centro madereros de Puerto Yartou, Puerto Arturo y La Paciencia habían llegado hacer los más importantes abastecedores de la región Magallánica y los mayores exportadores de madera hacia el sur argentino... (Martinic, 2009:164) realizadas por la firma Campos y Marcou quedan en pie las ruinas de lo que fue el galpón del aserradero, algunas casas $^{17}$, la olvidada pista de aterrizaje de 800 mts. de longitud, la deteriorada estructura del segundo muelle (Fig. 13) construido luego que el primero se destruyó al desplomarse el cerro tras el terremoto de 1949 y la caldera (Fig. 17) que fue traída flotando a través del seno Almirantazgo desde el ex aserradero La Paciencia.

En abril de 1978 Arturo Barrientos Leal (1908-1987) fue detenido por Carabineros en Caleta María, acusado de estafa en la venta de vacunos y es trasladado posteriormente a Punta Arenas dejando para siempre Caleta María. Desde entonces los terrenos que subarrendaba Barrientos pasaron a ser fiscales ${ }^{18}$. Con la retirada de Barrientos de Caleta María se produjo lo que don Cata denominó la "Fiebre de los toros" ya que, como una forma de pagar las deudas, Barrientos afirmó a sus deudores que en los campos de Caleta María quedaban más de 2000 vacunos lo que provocó la llegada de ilusos que dieron crédito a sus palabras. A pesar de la advertencias de don Cata de que era imposible que hubiese tal cantidad de animales en estancia "Vicuña", lugar

17 Construcciones que formaban parte de la antigua estancia Almirantazgo y después de la instalacion del aserradero de Caleta María. Ver Niemeyer,1978:10

18 Esta era la segunda vez que Arturo Barrientos era detenido, la primera detención fue por estafa de lana y días previos de dejar la prisión, según contaba, tuvo un extraño sueño con un número, al salir consiguió dinero y compró un boleto de lotería resultando ganador del premio. Con ese dinero compra los derechos de subarriendo de Caleta María a Lucio Genskowsky en 1973. 
donde culminaba el camino vehicular y que dista aproximadamente a $85 \mathrm{~km}$. de Caleta María, ya esperaban camiones para el transporte de vacunos mientras que por el seno Almirantazgo aparecían embarcaciones con el mismo fin. Finalmente los

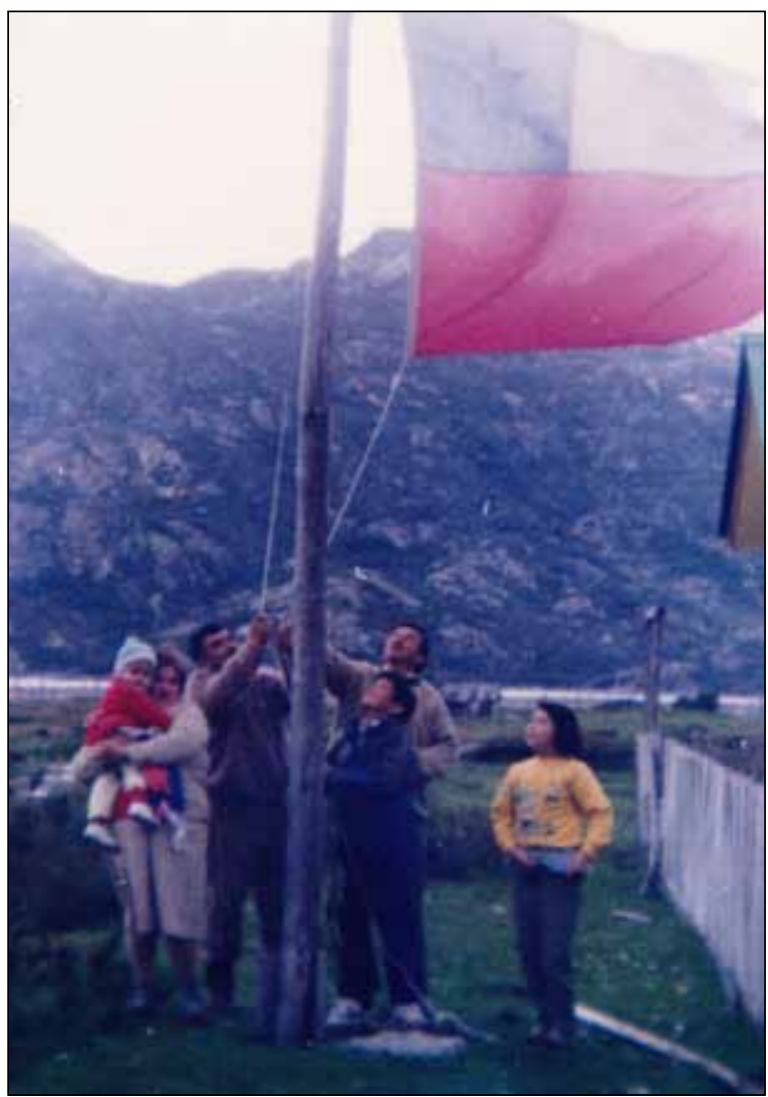

Fig. 7. Reinaldo Catalán junto a su familia izando la bandera chilena en Caleta María,1993.

(Foto gentileza de Reinaldo Catalán)

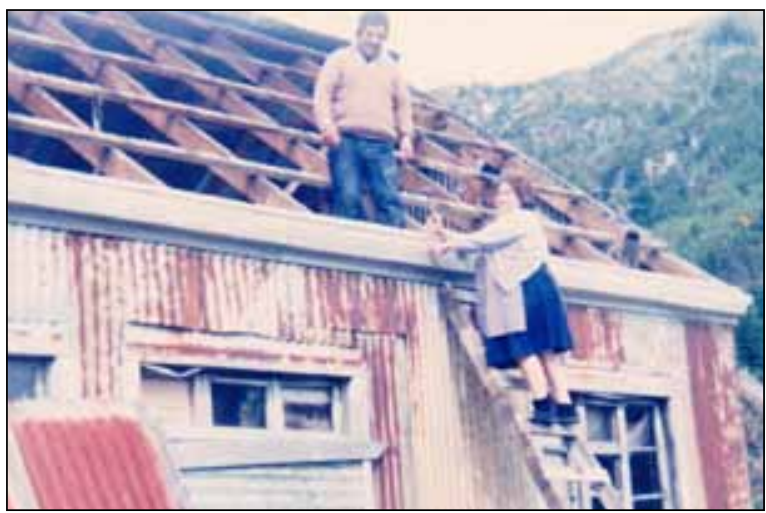

Fig. 9. Reinaldo Catalán y su esposa Sara Alvarado restaurando su vivienda en Caleta María,1986. (Foto gentileza de Reinaldo Catalán) buscadores de vacunos o bagualeros se dieron por vencidos. Con la partida de Arturo Barrientos de Caleta María, Reinaldo Catalán se convirtió en el único vecino del solitario lago Fagnano y poblador de sus alrededores.

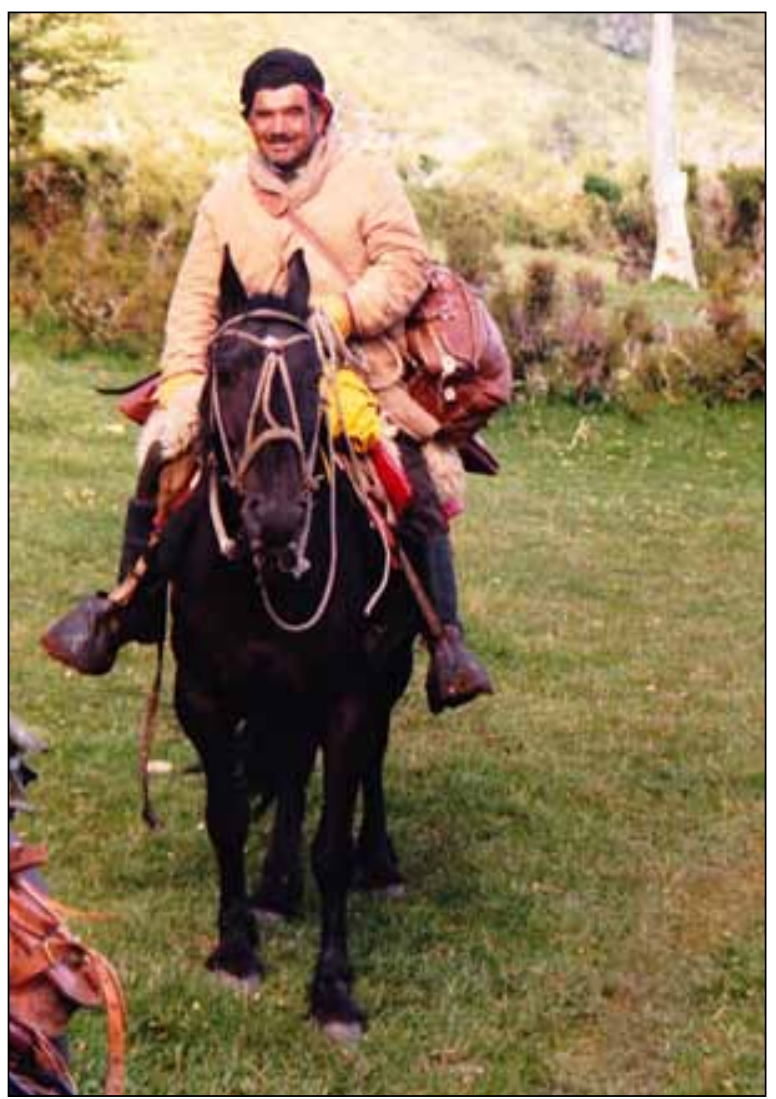

Fig. 8. Don Cata y su caballo Pele. (Foto gentileza de Reinaldo Catalán)

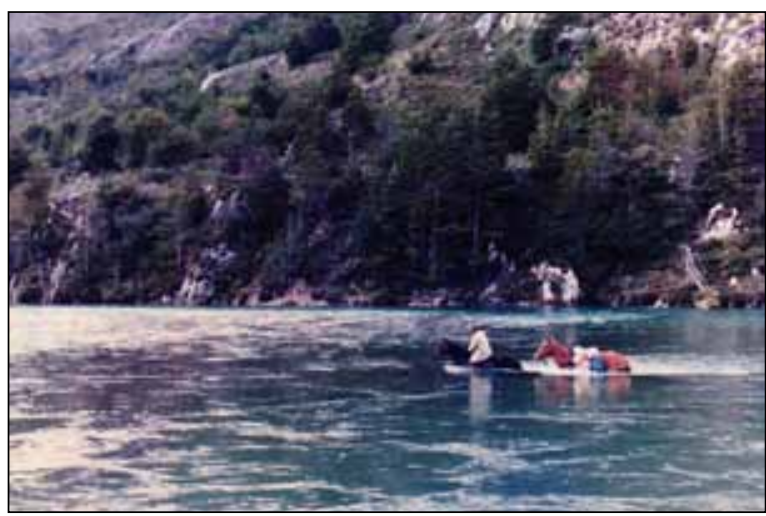

Fig. 10. Reinaldo Catalán cruzando el río Azopardo,1982.(Foto gentileza de Reinaldo Catalán) 


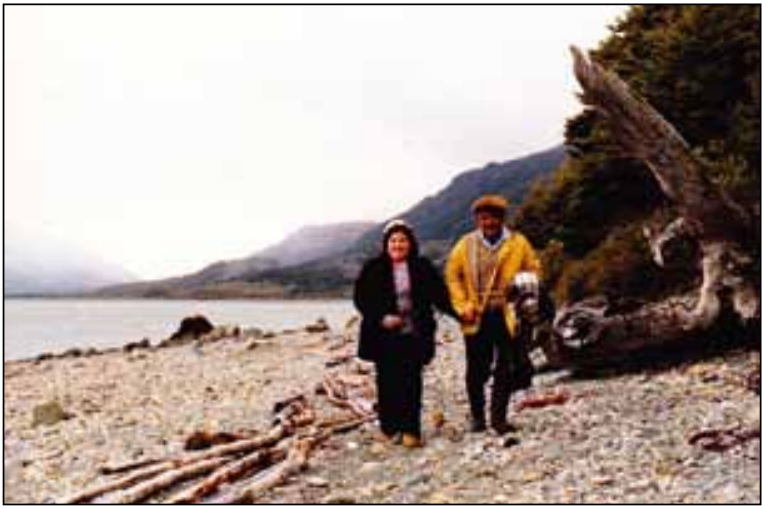

Fig. 11. Reinaldo Catalán junto a su esposa Sara Alvarado caminando a orillas del seno Almirantazgo,1988).

(Foto gentileza de Reinaldo Catalán)

La vida de los baqueanos después

de la expedición de 1978

Terminada y cumplida la misión los baqueanos regresaron sin novedad al sur del lago Fagnano montados en sus caballos. Llegando al lugar, Oyarzún tomó rumbo hacia Vicuña para retornar a Punta Arenas mientras que don Cata se quedó con Garay, que al breve tiempo se retiró para siempre de la isla. En 1979, un año después de la realización de la expedición Vicuña-Yendegaia, don Cata tuvo la oportunidad de visitar a Hans Niemeyer en su hogar ubicado en Santiago; en un ambiente familiar rememoraron la expedición contando las impresiones y anécdotas propias de estas aventuras. A fines de este año Francisco Oyarzún regresó al lago Fagnano para trabajar junto a don Cata en la captura de baguales que generalmente cruzaban la frontera. Don Cata recuerda que era un trabajo peligroso porque exponían sus vidas si es que eran sorprendidos por militares argentinos dado que los ánimos con el vecino país no eran de los mejores ${ }^{19}$. Más de alguna vez para evitar ser avistados, salieron sigilosamente en busca de los baguales bajo la luz de la luna. Como forma de combatir la soledad y poder compartir con otras personas, estos dos baqueanos, siempre que las condiciones climáticas fueran favorables, se embarcaban en una chalupa o chata y remaban desde Caleta María, por el seno Almirantazgo, hasta la localidad de La Paciencia en

191978 fue el año de mayor tensión del conflicto limítrofe entre Chile y Argentina denominado "La Crisis del Beagle".

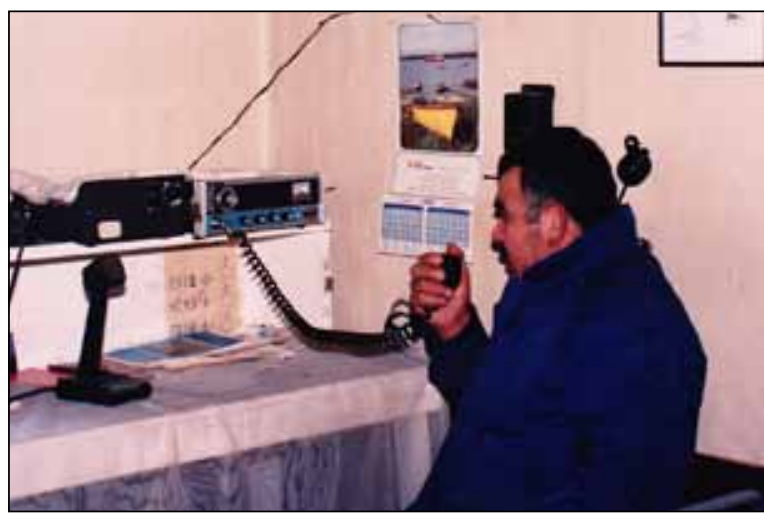

Fig. 12. Reinaldo Catalán comunicándose por vía radial,1994.(Foto gentileza de Reinaldo Catalán)

la cual se encontraban algunos trabajadores dedicados a la crianza de vacunos. Remar por el seno Almirantazgo no era una práctica extraña, Lucio Genskowsky Pietrogrande junto a su hijo Rodrigo y con uno de sus trabajadores apodado "Pecho de toro", en una oportunidad en la cual escaseaban los víveres y la embarcación que los iría a abastecer no llegaba, realizaron una fatigosa odisea de 27 horas de remo desde Caleta María hasta Puerto Arturo para poder comunicarse por radio a Punta Arenas.

En 1980 don Cata se radicó en Caleta María y fue aconsejado y ayudado, de forma desinteresada, en la tramitación de compra de los terrenos por el mayor de Carabineros de Chile Gustavo Aguirre Galleguillos de Porvenir el cual se sorprendió, luego de visitar el lago Fagnano, y aprecian lo remoto y extremo del mundo en donde vivía don Cata. Así empezó a realizar los trámites de compra que tardarían diez años. Junto con Oyarzún construyeron los cercos de su Caleta María y desde entonces don Cata viviría solitariamente allí y Oyarzún de igual forma al sur del lago Fagnano. Al cabo de una temporada Oyarzún se trasladó junto a sus animales a la localidad de La Paciencia, a orillas del seno Almirantazgo (Fig. 1), terrenos que arrendaba Francisco Gómez Andrade (1912-1995). Desde aquel momento Oyarzún estuvo habitando y recorriendo el valle La Paciencia por cerca de once años y visitando de vez en cuando Punta Arenas o Porvenir, para lo cual primero se trasladaba a estancia "Vicuña", tramo que realizaba en $12 \mathrm{hrs}$. a caballo, a través de lo que Oyarzún denomina las "picadas antiguas", las cuales en la actualidad están borradas por el paso del tiempo y la ausencia permanente del hombre. 
En 1986 Reinaldo Catalán contrajo matrimonio con Sara del Rosario Alvarado Guerrero (1945) fruto del cual nació su hija Karina (1990). $\mathrm{Su}$ padrino de matrimonio es quién fue su único vecino durante catorce años, Germán Genskowsky Middleton (1945) quien arribó en 1984 a la cuenca occidental y norte del lago Fagnano, terrenos que su padre Lucio subarrendó a mediados de la década del 60 y comienzos de la década del 70. En la actualidad Germán Genskowsky es el único vecino del solitario sector chileno del lago Fagnano.

Desde 1988 y gracias a la Armada de Chile don Cata empezó a trasladar a sus animales a Punta Arenas por la vía marítima dejando atrás veinte años de sacrificado arreo de más de $300 \mathrm{~km}$. desde el lago Fagnano a Porvenir. ¡El arreo más largo de tierra del fuego! En 1990 fue designado alcalde de mar (Fig. 12) asumiendo un importante rol en la zona y lo que a la vez le permitió, por primera vez dentro de 24 años, tener comunicación radial diaria con Punta Arenas.

El 22 de octubre de $1993^{20}$, después de 10 años de larga espera, don Cata se convirtió en el legítimo dueño de Caleta María. El precio original de los terrenos era $\$ 5.880 .000$ pero según nos cuenta las Fuerzas Armadas de Chile intercedieron, como una forma de agradecer a este sacrificado baqueano que tanto los ayudó en el reconocimiento de la zona y por la hospitalidad que siempre les brindó, para que los terrenos les fuesen regalados algo que no fue posible pero se consiguió una rebaja de $\$ 5$ millones de pesos efectuándose la compra en

20 Comprobante de ingreso 00151, Secretaría Regional ministerial de Bienes Nacionales XII región, 22 de octubre de 1993, Punta Arenas.

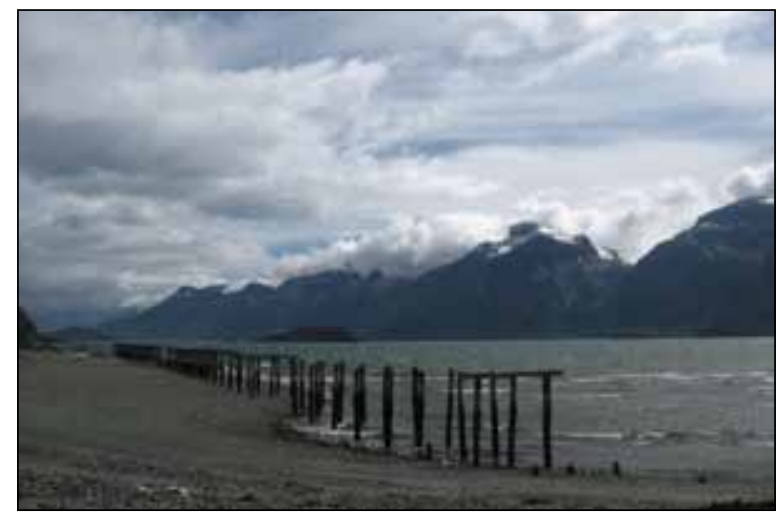

Fig. 13. Vestigio del segundo muelle construido por la Firma Campos y Marcou en Caleta María. (Foto del autor, 2011)
\$873.500. En este mismo año, Oyarzún se trasladó a los campos de su nuevo patrón y arrendatario de La Paciencia, Rusmir Vojnovic Masle, ubicados en las inmediaciones del faro Espíritu Santo, dejando atrás veintitrés años de vida entre las montañas y bosques del sur de la isla. Más tarde se va a trabajar a la estancia "Lucía" de su mismo patrón ubicada en la costa norte y occidental de la isla hasta marzo del 2010, año en que abandona definitivamente la isla y el sacrificado trabajo al cual dedicó sesenta años de su agitada vida. Reinaldo Catalán por su parte, debido a problemas de salud, en $1998^{21}$ vendió sus terrenos en $\$ 80.000 .000$ a Julio Contreras (actual dueño de Caleta María) y se retiró para siempre del lugar en 2001 después de terminar de sacar sus últimos vacunos. Atrás quedan cuarenta años de vida de esfuerzo y soberanía acompañados de las inclemencias del clima en su máxima expresión.

Don Cata, siempre enérgico, a sus 83 años y frente a las dudas de algunos montó nuevamente a caballo y volvió a visitar junto a su hija la solitaria Caleta María en enero del 2011, cabalgando desde la desembocadura del lago Fagnano hasta la orilla del seno Almirantazgo tal como lo hiciera por más de treinta años, y espera visitar Caleta María en automóvil cuando esté finalizado el ramal que por ahora, y esperemos que así sea para siempre, lleva el nombre de Huella Catalán. Francisco Oyarzún por su parte ya no volvería a la isla, sin embargo no descarta hacerlo junto a su familia cuando la senda de penetración Vicuña - Yendegaia esté finalizada.

21 Consultar: "Don Cata deja Tierra del Fuego. Reinaldo Catalán Oporto: 25 años de soberanía en seno Almirantazgo". El Magallanes 8 de marzo 1998.

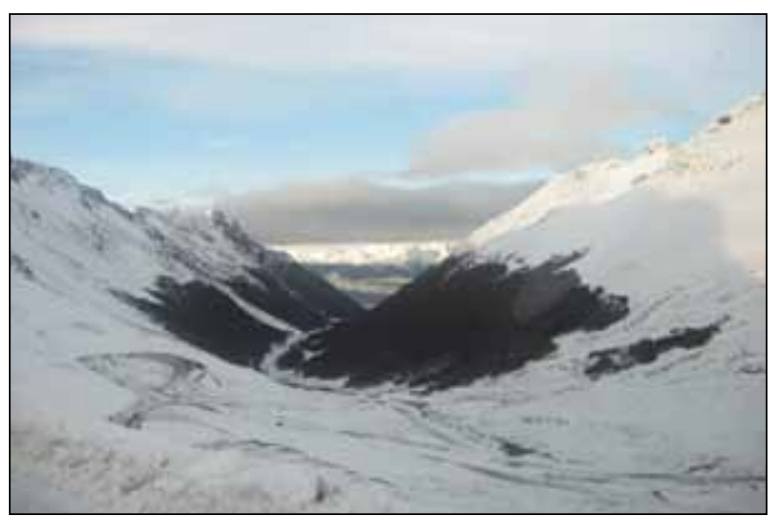

Fig. 14. Cañadón Genskowsky. Al centro se aprecia la senda de penetración y al fondo el lago Fagnano (Foto del autor, mayo 2011) 


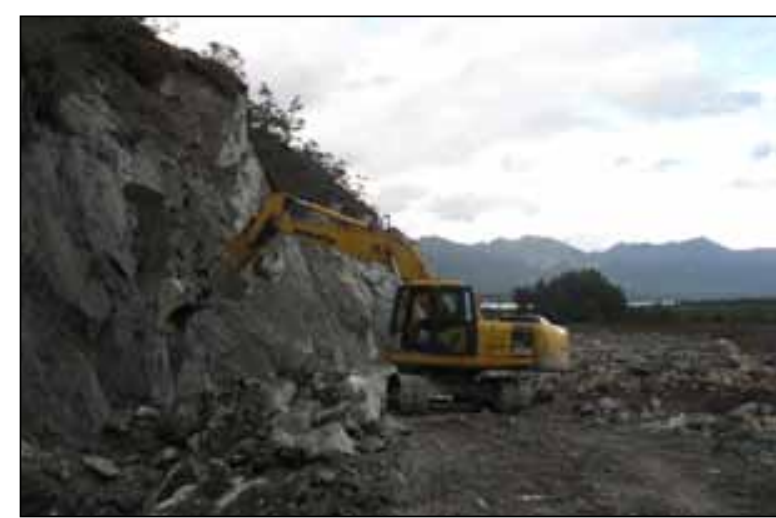

Fig. 15. Construcción de la Senda de penetración Vicuña Yendegaia en el valle Betbeder. (Foto del autor, 2011).

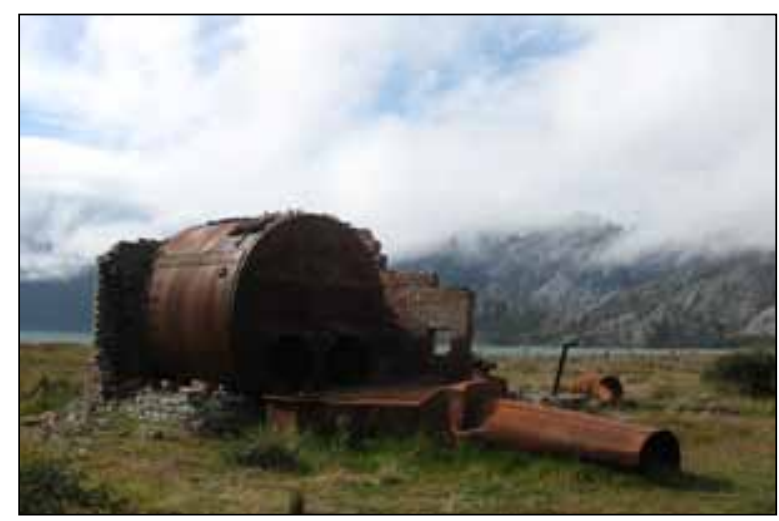

Fig. 17. Vestigio de la caldera del ex aserradero Caleta María ( Foto del autor, 2011)

Hacer una fogata, ensillar su caballo, preparar sus pilchas $^{22}$, silbar a sus perros y caminar por las lejanías es parte de sus recuerdos; ya es tiempo de descansar.

En la actualidad, de los siete expedicionarios de 1978 sólo viven Reinaldo Catalán Oporto (84 años), Francisco Oyarzún Díaz (77 años) y Arístides Vargas Morris (78 años). Víctor Garay Bórquez fallece a la temprana edad de 26 años el 7 de diciembre de 1981 en Punta Arenas, Eduardo Larravide Lynch fallece en Punta Arenas el 21 de junio de 1998 a la edad de 68 años, Hans Niemeyer Fernández fallece a los 84 años de edad en Coquimbo el 17 de octubre del 2005 y el suboficial Luis Arata Campodónico el 20 de septiembre del 2007 a los 66 años de edad en el hospital Militar de Santiago luego de enfrentar el año 2006 a la justicia por el denominado "Caso

22 Pilchas: Pertenencias personales.

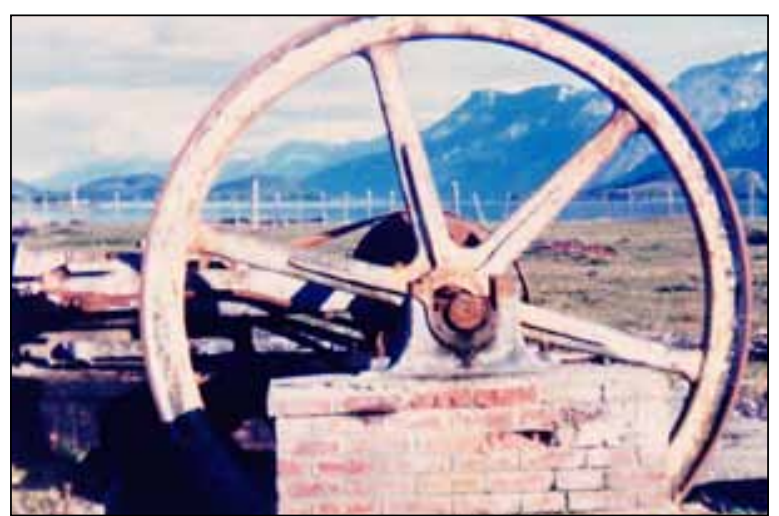

Fig. 16. Vestigio, de una parte, de la caldera del aserradero Caleta María,1987.(Foto gentileza de Reinaldo Catalán)

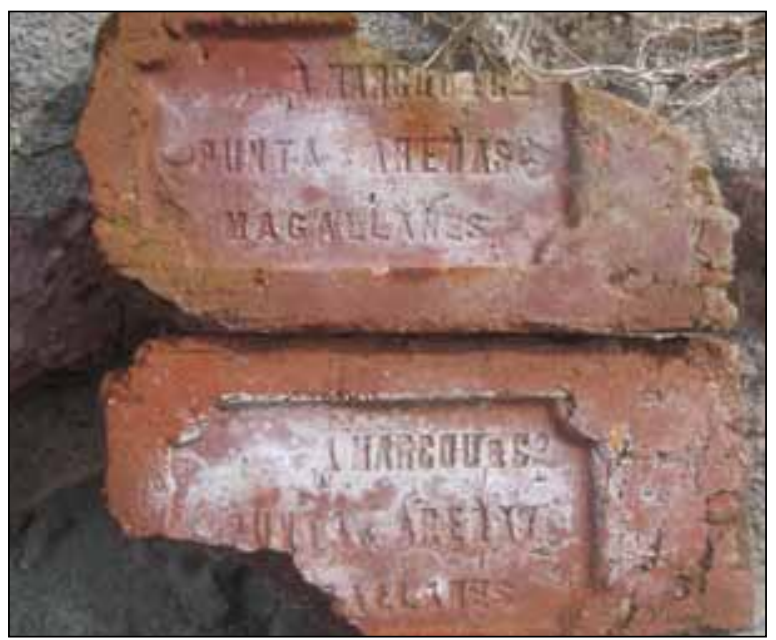

Fig. 18. Ladrillos elaborados por la fabrica de ladrillos de Alejo A. Marcou (padre de Alejo Segundo Marcou, quien inicio junto a Francisco Campos M. el aserradero Caleta María) y utilizados en la construcción de la caldera del aserradero Caleta María. Nótese la inscripción A. Marcou y Cia. (Foto del autor, 2011)

Porvenir", suceso ocurrido en septiembre de 1973 en dicha localidad ${ }^{23}$.

Anécdotas de la expedición de 1978 y una casa misteriosa

Personalmente creo que hay anécdotas, que me comentó don Cata, ocurridas durante el desarrollo de la expedición de 1978, no expuestas tanto en

23 Luis Arata Campodónico fue uno de los tres autores del homicidio calificado contra tres presos políticos acontecido la noche del 29 de septiembre de 1973. El Mercurio 9 de agosto 2006 . 
el artículo como en el libro desarrollado por Hans Niemeyer, de las cuales no puedo privar al lector. Cuando los expedicionarios arribaron a la estancia Yendegaia don Cata dijo a la comisión: “... Bueno, yo cumplí mi palabra y los traje sin novedad, allá adelante esta la casa, yo llego hasta aquí no más. Uds. no confiaron en mí. Supe que cuando estuvimos en el Puesto de Lata (Francisco Oyarzún se lo comentó) y mientras yo había salido a reconocer el camino uds. se comunicaron por radio a Punta Arenas y dijeron que el hombre que los guiaba los tenía perdidos, que estaban en Argentina”. Don Cata continuó. "... Como no se dieron cuenta que en el puesto de lata había escrito en sus paredes puros apellidos chilenos". A pesar de las disculpas que dieron los expedicionarios estas no fueron válidas para don Cata.

Otra anécdota es similar a lo que acontece en la canción "El viento y el roble" del cantautor José Larralde. Cuando los expedicionarios se dirigían desde Caleta María hacia el rancho de don Cata ubicado en la orilla sur del lago Fagnano, Hans Niemeyer le comentó a don Cata en un tono altanero: ... ¿Cómo es posible que los ingenieros magallánicos se hayan perdido y no fueran capaces de haber realizado este viaje antes que nosotros? (cabe recordar que expediciones anteriores habían fracasado). Don Cata respondió en el mismo idioma tal como el viento lo hizo al roble en la canción ya mencionada: ... don Hans, esa gente no tuvo la suerte que Ud. tiene. Yo no los pude acompañar y si lo hubiese hecho, Ud. no tendría para que haber venido para acá.

Si hay algo que don Cata recuerda hasta el día de hoy es la ingratitud de los ingenieros Izquierdo y Valenzuela. Don Cata comenta: ... Con todo lo que hice para que la expedición saliera bien y toda la mortificación que eso significó, salía junto al hacha en busca del camino para el día siguiente, presté caballos, monturas, les di alojamiento, comida y de eso lo ingenieros Izquierdo y Valenzuela tenían conocimiento y más encima todo lo hice voluntariamente. Cuando ellos llegaron a Yendegaia ni siquiera se bajaron del barco para darme las gracias y menos me llevaron un regalito como agradecimiento.

Por último quisiera agregar algo en cierto grado curioso que me comentó don Cata cuando le pregunte acerca del pueblo originario de la isla; los Selknam y precisamente si alguna vez encontró algún resto o indicio en sus recorridos por la zona, como ya sabemos, de esta exterminada raza. Me respondió que nunca encontró nada pero que sin embargo existió un mito en relación a lo que le preguntaba. Se trataba de una casa a la cual se le denominaba "La casa del misterio" ubicada en las inmediaciones de Caleta María, de la cual no se sabía quien la había construido y con que fin. Esta casa tenía en su interior dos piezas amobladas con literas y un comedor, el misterio radica en que no tenía puerta o aberturas por donde ingresar y tampoco tenía indicio de haberla tenido alguna vez, sin embargo tenía una abertura que no superaba los $50 \mathrm{~cm}$. x 50 $\mathrm{cm}$. y se decía que por allí Los Menéndez habían arrojado los cadáveres de los inocentes Selknam (i!).

\section{RECONOCIMIENTO A LOS BAQUEANOS}

La expedición de febrero-marzo de 1978 debe ser considerada como parte de la historia oficial de Tierra del Fuego y los baqueanos Reinaldo Catalán Oporto y Francisco Oyarzún Díaz deben ser reconocidos por su transcendental participación en el origen de la senda de penetración VicuñaYendegaia. No podemos ser ingratos con estos verdaderos hombres de las montañas fueguinas y dejarlos en el anonimato aunque ellos no esperen reconocimiento alguno. Denominar algún significativo hecho geográfico con sus nombres es quizás una forma de reconocerlos. Muchos transitarán por esta futura senda de penetración y lo más probable será que lo hagan sin saber su origen y protagonistas. Esta expedición fue particular al menos por cuatro motivos, el primero, por la participación de dos baqueanos, únicos habitantes y conocedores de la zona. Arístides Vargas Morris (maestro de cocina de la expedición) los recuerda como profundos conocedores de su tierra y que a ellos se debió que la expedición no se extraviase y fracasara. Segundo, por la participación de una figura de la arqueología chilena, Hans Niemeyer Fernández. Tercero, por el significado que proporcionará este camino a la isla y cuarto porque curiosamente se realizó el mismo año del conflicto con Argentina. Si tal circunstancia habrá tenido pudo apresurar la construcción de este camino, como forma de hacer soberanía, queda abierto a una posible investigación.

La ayuda de Catalán fue decisiva para el éxito de la expedición, lo atestiguan las cartas que le fueron enviadas en el transcurso de la expedición de 


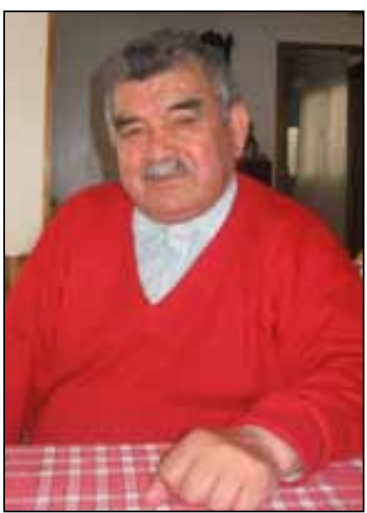

Fig. 19. Reinaldo Catalán O., Don Cata. (foto del autor, 2011)

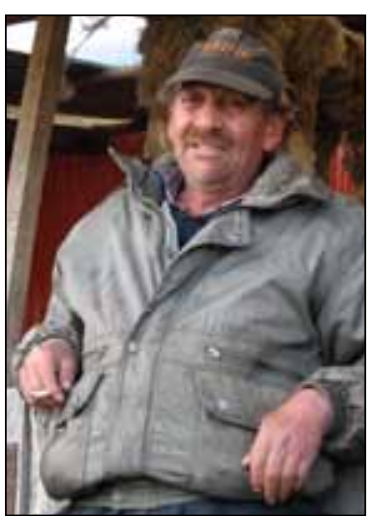

Fig. 20. José Maldonado M., El Rubio. (foto del autor, 2011)

$1978^{24}$. Catalán como siempre cumplió su palabra, al comprometerse a guiar a cualquier comisión que marchara al sur de Tierra del Fuego, luego de que una expedición con el mismo fin que la dirigida por Niemeyer se extraviara en las inmediaciones del lago Deseado en enero de 1978, en tal oportunidad Catalán no los pudo acompañar porque se dirigía con sus vacunos a Porvenir. Nadie más que él conocía la ruta de Caleta María a Yendegaia. Sin embargo lo que él conocía, sólo lo había realizado a pie, por lo que aventurarse con caballos tiene una connotación mayor por la dificultad que significa transitar por bosques casi impenetrables, por la agotadora turba y las inclinadas y filosas cuestas. Catalán no sólo aportó para esta expedición sino también al conocimiento y soberanía de esta apartada zona. Colaboró, en forma desinteresada económicamente, con toda comisión de las Fuerzas Armadas de Chile (Fig. 5 y 6), autoridades gubernamentales ${ }^{25}$, turistas y exploradores ${ }^{26}$ que se lo solicitaron para trasponer el cordón La Paciencia, cordillera Darwin y sus alrededores, quienes dejaron escritos sus agradecimientos en un libro que don Cata tenía para dicho fin.

24 Ver apéndice II y fig. 48 y 49.

25 Consultar: La Prensa Austral 27 de enero 1989. Pág. 6.

26 Consultar: "A cruzar Tierra del Fuego. Por primera vez, expedición intenta cruzar Tierra del Fuego en motocicleta". Revista del Domingo, 18 enero 1987, N 1048. Reportaje de Ricardo Astorga. Págs. 7-9. El Mercurio.

"Se hace camino al andar. Abriendo ruta al seno Almirantazgo". Suplemento Dominical del Magallanes. semana 24 al 30 de enero 1988. Por Pedro Aretxabala Benito. La Prensa Austral 16 de marzo 1994. Pág. 8

"Dominio en cielos Australes". Camaradas. IV Brigada Aérea. Mayo $N^{\circ}$ 19. Santiago, Chile. Año MCMXCII. Pág. 3.

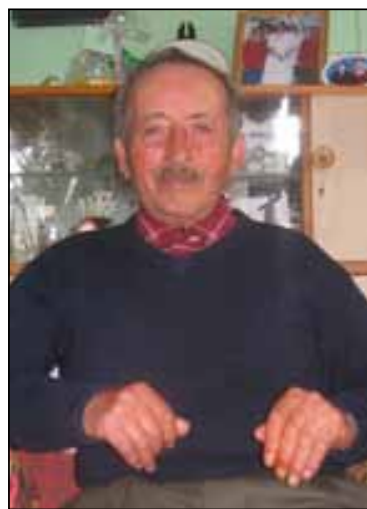

Fig. 21. Francisco Oyarzún D. (foto del autor, 2011)

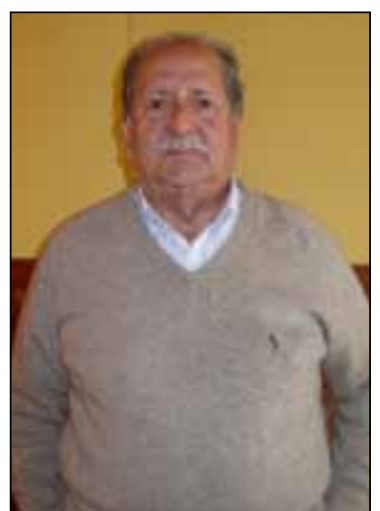

Fig. 22. Arístides Vargas M. (foto del autor, 2011)
De las muchas veces que Catalán y Oyarzún tuvieron que socorrerse y ayudar a otros que se aventuraban por la zona, frente a las adversidades e innumerables dificultades que les impuso el inhóspito y salvaje sur de Tierra del Fuego nos habla de la solidaridad, humanidad y lealtad de estos hombres sencillos y de sólo estudios básicos. Lástima que escritores chilenos como Juan Marín, Juan Magal, Mariano Latorre, Reinaldo Lomboy, Oscar Castro (don Cata tiene su propia versión, con su caballo Pele (Fig.8), del cuento "Lucero" de este autor), Hugo Vera Miranda, Oreste Plath no los conocieran, de seguro los hubiesen incluido en algunos de sus libros.

Catalán y Oyarzún, por ser los únicos habitantes permanentes por más de cuarenta años en el sur de Tierra del Fuego fueron protagonistas y testigos de un cúmulo de aventuras, vicisitudes, anécdotas y sucesos, y por ende portadores de relatos esenciales para la construcción de la desconocida historia del sur de Tierra del Fuego (Chile) entre el año 1950 y 2000 . Muchos fueron los hombres que trabajaron esporádicamente, contertulios de don Cata y Oyarzún, en este apartado rincón de la isla y que pasaron a convertirse en unos verdaderos personajes anónimos dignos de ser recordados, de ellos no sabemos más que escasos antecedentes: El Indio Covi, El Pecho de Toro, El Come Mosca, Humberto Ojeda, Vargas (quien se suicidó en La Paciencia), Mario Cum, El tres naciones, El espanta la virgen, El piojo Catelicán, Leni, Luis Machete Muñoz, Naín Coyopay, los hermanos Vidal, Mate Hache Hernández, El finado Gringo Osman, Pedro Cheuquemán, Francisco Ojeda, Oscar El Chaya Garay, etc. 


\section{INICIO DE LA CONSTRUCCIÓN DE LA SENDA DE PENETRACIÓN VICUÑA-YENDEGAIA}

La senda de penetración Vicuña-Yendegaia se empezó a construir a fines de 1994, con principio en el puente del río Rasmussen y a cargo de su construcción, desde su inicio y hasta la actualidad, ha estado ha cargo del Cuerpo Militar del Trabajo (C.M.T). En la actualidad los trabajos de construcción de la senda de penetración Vicuña-Yendegaia presentan un cincuenta por ciento de avance de una longitud total de $139 \mathrm{~km}$. los que han superado el rió Azopardo y se han adentrado $7 \mathrm{~km}$. al interior del valle Betbeder (Fig. 15) en busca del paso de Las Lagunas (700 m.s.m.), portezuelo estratégico para trasponer la cordillera Darwin descubierto por el explorador Skottsberg en 1908. Lo que respecta al ramal "Caleta María", que conectará el lago Fagnano con el seno Almirantazgo, se han construido $4 \mathrm{~km}$. de los $13 \mathrm{~km}$. que contempla dicha ruta.

El 23 de enero del 2009 la Presidenta Michelle Bachelet visitó el campamento del Cuerpo Militar del Trabajo, establecido en la vecindad del lago Fagnano, allí destacó que este proyecto en la zona austral del país busca consolidar el territorio y la soberanía nacional, integrar zona de potencialidad productiva (ganadería, salmonicultura, forestal, etc.), dar continuidad al territorio extendiendo las vías de conexión existentes, auanzar en la integración regional chileno-argentina y fomentar el desarrollo turístico en la región gracias a la incorporación de áreas de inigualable belleza, prácticamente inexploradas y despobladas al turismo nacional e internacional...27

Finalizada esta promisoria vía, cosa estimada para el 2019, Caleta María ya no será el lugar donde termina el seno Almirantazgo, también será el inicio del mismo en un sentido oríente-poniente. Sin duda esta obra permitirá una percepción más compleja y diversa a Tierra del Fuego (Chile) dado que se podrá traspasar de lo horizontal de la pampa a lo vertical de los montes y de la cordillera, de lo amarillo de la estepa a lo verde de los soberbios bosques que resistieron a la depredación del hombre y al blanco de los hielos que se posan en las cumbres de la cordillera Darwin o Andes Fueguinos. Gracias a esta

27 La Prensa Austral, 24 enero 2009 senda de penetración podremos conocer el último refugio de los primeros y originales habitantes de la isla; los Selknam, además de hacernos ver que Tierra del Fuego es un territorio y no una serie de localidades. También permitirá comprender parte de esa dimensión fantástica sublime que atrajo a comienzos del siglo XX a los exploradores Nordenskjold (1895), Skottsberg (1908), De Agostini (1914), Rockwell Kent (1922), Pluschow (1928) y Vaino Auer (1929).

\section{COMENTARIOS FINALES}

Hoy en día estamos en deuda con la historia de Tierra del Fuego, algo ya manifestado por el escritor Benjamín Subercaseaux en 1940 con las siguientes palabras: [...] Son esos recuerdos de su trágico pasado que han conferido a nuestra Tierra del Fuego una atmosfera romántica, conocida en todos los países, menos el nuestro. Los chilenos somos los únicos que seguimos ignorando la riqueza emotiva y el cúmulo de aventuras que encierran estos parajes. Aquí como en tantas partes de nuestra tierra, se advierte esa falta de posesión efectiva de los ambientes, esa impresión de recién llegados que todo lo ignoran, o mejor, de nuevos ocupantes de una gran casa que no supieron amoblar ni comprender ${ }^{28}$. El nuevo museo de Porvenir es quizás el primer paso para saldar esta deuda, pero ¿La historia sólo está en los museos? Tierra del Fuego es por distintos motivos un caso particular y único en el que su singular historia se encuentra dispersa por el territorio a través de vestigios aún sin descifrar, los cuales se conservan intactos o alterados por factores naturales. Concentrar la historia y dar por hecho que ésta puede verse sólo en los museos puede ser cause de que nos olvidemos del lugar desde donde se forjó, siendo este el verdadero espacio de exposición al que debemos proteger dado el singular caso de la isla. Tierra del Fuego es una tierra a la que hay que ir sin prejuicios, hay que observarla y comprenderla, lo que significa conocer su pasado y presente, a su gente y ahondar en las profundidades de su alma, algo que ha sido escasamente capturado por la fotografía. Podríamos decir que la expedición de febrero- marzo de 1978 no dejó vestigios tangibles, sólo escritos y fotografías que 
posiblemente se exhibirán en museos, pero ¿No es acaso la senda de penetración Vicuña-Yendegaia un gran vestigio que nos dejan Reinaldo Catalán, Francisco Oyarzún, el equipo que conformó la expedición de febrero-marzo de 1978 y las personas anónimas que han estado y están involucradas en su construcción? Bajo esta mirada sería interesante que una vez finalizada esta trascendente obra vial encontrarnos en su trayecto con intervenciones de índole escultórica-arquitectónica del espíritu de Eduardo Chillida, Federico Assler, por nombrar algunos, que retengan en el tiempo el recuerdo de la memorable expedición allí, donde se originó.

Y así, lo que por mucho tiempo fue sólo contemplado por los ojos de Catalán y Oyarzún ahora podrá ser visto por muchos. Estos hombres ya dejaron su huella por la cual muchos transitarán sin tantos sacrificios y con menos aventuras.

\section{AGRADECIMIENTOS}

A Reinaldo Catalán O. y familia, a Francisco Oyarzún D. a quienes se les agradece su generosa cooperación para desarrollar el presente documento que sin ellos no hubiese sido posible. A Marcela Larravide D. por sus sugerencias y gentileza de facilitar y compartir, de forma desinteresada, las fotografías tomadas por su padre. Se agradece a don Mateo Martinic (Instituto de la Patagonia) por su apoyo y sugerencias y a quienes colaboraron en la elaboración de este documento: Margarita Gallardo Ule, Gabriel Oyarzún Oyarzo, Paulino Vidal Vidal, Daniela Ambrosetti Garrido, Andrea Aránguiz Núñez, (Punta Arenas). Nancy Varas Águila y familia (Porvenir) Germán Genskowsky y su esposa Marisela (Estancia Lago Fagnano) Julio Cubillos, Alejandro Urriaga, Ricardo Sánchez "Maestro" José Silva, Julio Flánega (C.M.T.)

\section{FUENTES DE CONSULTA}

a) Inéditas

Cartas de Hans Niemeyer Fernández y Luis Arata Campodónico dirigidas a Reinaldo Catalán Oporto, 4 de marzo 1978.

Fotografías tomadas por Eduardo Larravide Lynch.

b) Impresas

BAERISWYL, D. 2003. Arquitectura en Punta Arenas casas de maderas. Hielos Antárticos, Punta Arenas.

MARTINIC, M. 2009 [1998]. La tierra de los fuegos. Municipalidad de Porvenir, Punta Arenas.

MIHOVILOVIC, N. 1974. Entre el cielo y el silencio. Pineda libros, Santiago.

MINISTERIO DE OBRAS PÚBLICAS. 1978. Proyecto de factibilidad técnica de un camino de estancia Vicuña a Yendegaia, Tierra del Fuego- XII región. Punta Arenas. 116 pp. MS.

NIEMEYER, H. 1978. Expedición de estancia Vicuña a bahía Yendegaia en la isla Grande de Tierra del Fuego. En: Expedición a Chile, cuadernos 1 y 2 de los fascículos 48 y 49 respectivamente. Gabriela Mistral, Punta Arenas.

SKOTTSBERG, C. 2004. La Patagonia Salvaje. Zagier y Urruty. Ushuaia.

SUBERCASEAUX, B. 2005. Chile o una loca geografía. Editorial Universitaria. Santiago.

TRONCOSO, A.; V. CASTRO Y L. NÚÑEZ. 2006. Obituario Hans Niemeyer Fernández (1921-2005). Chungara, Revista de Antropología Chilena, 38(2): 165-171.

c) Entrevistas

- Reinaldo Catalán O., Marzo-abril 2011.

- Francisco Oyarzún D., Marzo-abril 2011. 


\section{APÉNDICE I $/ "$ \\ EXPEDICIÓN DE ESTANCIA VICUÑA A BAHÍA YENDEGAIA EN LA ISLA GRANDE DE TIERRA DEL FUEGO}

\section{INTRODUCCIÓN}

Transcurría la tarde del 31 de enero. Ya me disponía a abandonar mi oficina para irme a casa y terminar de cargar el Land Rover con el cual partiría al día siguiente a Coquimbo de vacaciones, cuando me llama por teléfono mi amigo y colega Sergio Silva. Indicaba dos motivos por su llamada. El primero era un asunto administrativo de ninguna importancia. El segundo era el ofrecimiento de que me hiciera cargo de una expedición en la Isla Grande de Tierra del Fuego. En la noche me explicaría de que se trataba. Me dejó perplejo. ¿Cómo alguien podía acordarse de mí para que realizara tal comisión? Había soñado muchas veces con eso, pero encontraba que era un poco tarde. Sin embargo fui aquella noche a hablar con Sergio. La secretaría Regional de Obras Publicas de la XII Región, le encomendaba a la firma de ingenieros consultores Sergio Silva y Víctor Bogado el análisis de factibilidad técnica de la construcción de un camino que partiendo de la Estancia Vicuña de la Tierra del Fuego, condujera a la bahía Yendegaia, en la costa norte del Canal Beagle. Se trataba de un camino de soberanía y de desarrollo turístico en una zona pletórica de bellezas naturales: ríos, lagos, bosques, glaciares, montañas, etc., todo en un paisaje casi no hollado por el hombre.

La intendencia de la XII región estaba vivamente interesada en ello y sus autoridades impulsaban el proyecto. Le expliqué que tenía compromisos por cumplir. En la Cordillera de Copiapó me esperaban para realizar la expedición arqueológica que emprendo anualmente en la zona. Estaba todo avisado. Quedaron de esperar mi regreso a mediados de febrero. Entre tanto Sergio Silva fue a Punta Arenas, contrato al constructor civil don Eduardo Larravide Lynch, experto en la construcción de caminos en la región, para que se preocupara de conseguir los caballos, aperos, víveres, una persona que pudiera hacerse cargo de la cocina durante el viaje, y otros aspectos de la organización logística a los que hay que atender en estos casos. Viajé de Coquimbo a Santiago el día 16 de febrero. Aquí dispuse de tres días para preocuparme de mi equipo personal, la adquisición de carpas y de sacos de dormir, embalaje de mi montura, etc. y viajé a Punta Arenas el día 20 de ese mes.

Alli conocí a mis compañeros de la próxima aventura, además de Larravide, formaría parte de ella el sargento del Ejército don Luis Arata, quien tendría a su cargo las comunicaciones radiales permanentes con la base; y el funcionario de Obras Públicas, don Arístides Vargas Morris quien desempeñaría el cargo de cocinero haciendo uso de sus vacaciones. Más adelante encontraríamos en Estancia Vicuña a don Francisco Oyarzún Díaz oriundo de Chiloé y afincado por muchos años en Magallanes; y durante el desarrollo de la expedición a don Reinaldo Catalán Oporto, natural de la provincia de Llanquihue ${ }^{29}$ quien vive en la ribera sur del lago Fagnano hace 12 años intentando la crianza de animales vacunos, y su ayudante Víctor Garay Bórquez, natural de Chiloé.

Me trasladé a Punta Arenas desde Santiago el día 20 de febrero acompañado por el ingeniero de la firma consultora don Hugo Valenzuela, quien actuaba como coordinador del proyecto. Tras algunos días de ajetreo en torno a finiquitar las compras, embalar cuidadosamente los víveres, tomar contacto con las autoridades locales, etc., el grupo expedicionario atravesó, con excelente tiempo, el Estrecho de Magallanes el día 23 de febrero en la barcaza Melinka, de Punta Arenas a Porvenir. Casi inmediatamente nos trasladamos

\footnotetext{
Reproducido del Artículo de Expedición a Chile, ver Niemeyer, 1978.

* Las fotografías hasta ahora inéditas y presentadas a continuación, fueron tomadas por Eduardo Larravide Lynch.

29 Es natural de Osorno y no de Llanquihue como se indica en el texto.
} 
a la estancia Vicuña ${ }^{30}$ en vehículos motorizados llegando cerca de las 10 pm, después de pasar a varios puntos del camino recogiendo aperos, etc. En la casa de la estancia, que se sitúa en el terminal del camino y a 200 m.s.m., el grupo fue hospedado por el señor Jorge Quiñones, concesionario de estos campos. La estancia Vicuña pasó a ser el Campamento $N^{\circ} 1$ de la expedición.

Al día siguiente, instalada ya la comisión en el lugar de partida, el ingeniero Valenzuela regresó a primera hora a Porvenir y de ahí a Punta Arenas. Dicho día se destinó en Vicuña a hacer las cargas debidamente contrapesadas. Llegó después del almuerzo el campañista Luis Oyarzún ${ }^{31}$ y en la noche, ya oscuro, arribaron los caballos que habían sido facilitados por la estancia Cameron y otros por el señor Fugellie de Pampa Guanaco. La dotación de animales fue completada ajustadamente con la adquisición de dos caballos particulares, "Panchito y Cuyuyo". Serían los que dieron más quehacer durante el viaje.

\section{CUERPO EXPEDICIONARIO 32}

La jefatura de la expedición fue confinada a Hans Niemeyer Fernández (57 años) de vasta experiencia en expediciones geográficas y reconocimientos técnicos a lo largo del país. El constructor civil don Eduardo Larravide Lynch (48 años), residente en Punta Arenas, tuvo a su cargo la organización previa de la expedición, sobre todo en lo que se refiere a conseguir al primer campañista ${ }^{33}$, la caballada y sus aperos,

30 El nombre de esta localidad proviene del apellido del abogado que hizo las gestiones para conseguir la antigua concesión de los campos ante el gobierno chileno (Niemeyer, 1978:4)

31 El nombre es Francisco y no Luís.

32 Reproducido de MOP, 1978 , parece necesario exponerla ya que detalla de mejor forma que en el articulo publicado en Expedición a Chile (Niemeyer ,1978)

33 Francisco Oyarzún se encontraba trabajando al sur del lago Fagnano en los días que antecedieron al inicio de la expedición, pero se dio la coincidencia que cuando Larravide viajó a la estancia Vicuña a contratar algún baqueano para que guíe a la expedición, Oyarzún se encontraba en ella hace un día porque había ido a realizar un tramite. De no haberse encontrado con Oyarzún, que era una de las pocas personas que conocía la huella Vicuña - Caleta María, lo más probable es que se hubiese tenido que contactar a Reinaldo Catalán para que fuera a buscar a la comisión a Vicuña. adquisición de víveres y algunos equipos, etc., pero su mayor aporte consistiría en su experiencia técnica en la XII región, particularmente su experiencia en el trazado y construcción de caminos de Enap ${ }^{34}$.

El tercer miembro fue el suboficial de Ejército don Luis Arata Campodónico (37 años) entrenado para las vicisitudes que se esperaban en la excursión y con experiencia previa en el área tuvo la importantísima misión de mantener diaria comunicación radial con su estación de base en Porvenir. Pertenece actualmente a la dotación del Regimiento Caupolicán.

Don Arístides Vargas Morris (45 años), funcionario administrativo de la Dirección General de Obras Públicas de Punta Arenas, gastó su tiempo de vacaciones en acompañar a la expedición en calidad de maestro de cocina ${ }^{35}$, cargo que desempeñó a entera satisfacción no obstante los sacrificios superiores a lo esperado.

La expedición contó con dos excelentes baqueanos o campañistas, como se les llama en la zona. El primero, quien inició su trabajo en la estancia Vicuña, fue don Francisco Oyarzún Días (45 años), oriundo de Chiloé y afincado por muchos años en la región de Magallanes. Fue el único campañista con quien contó la expedición en el recorrido desde estancia Vicuña hasta Caleta María. Ese era el tramo que él había transitado con anterioridad.

El segundo baqueano fue don Reinaldo Catalán Oporto (52 años) natural de la provincia de Llanquihue ${ }^{36}$ y radicado en Tierra del Fuego desde 1955. Hace 12 años que vive en la ribera sur del Lago Fagnano e intenta la crianza de animales vacunos venciendo innumerables dificultades, derivadas especialmente de la falta de caminos y otros medios. Conocía hasta poco más al sur del Paso de las Lagunas. Su desinteresada colaboración fue decisiva para el éxito de la expedición, toda vez que terminada una jornada salía a pie en busca de la ruta a seguir al día siguiente.

34 Eduardo Larravide se desempeñó como funcionario en el Ministerio de Obras Públicas y Dirección de Vialidad y trabajó simultáneamente para ENAP. A partir de 1973 y por cerca de 18 años se dedicó al ejercicio libre de la profesión.

35 Actividad que fue remunerada.

36 Ver nota 29. 
Participó junto con Catalán, en calidad de ayudante de campañista el joven Víctor Garay Bórquez, natural de Chiloé, quien ayudó eficientemente en el manejo de los cargueros.

\section{INICIO DE LA EXPEDICIÓN ${ }^{37}$}

El día 25 finalmente partimos al medio día llevando por meta el punto conocido como corrales de Marcou, a orillas del rio Rasmussen o Bellavista (...) este tramo ofreció solo en pequeños paños dificultades de turbales ${ }^{38}$. Fueron los primeros contactos con el escollo más importante que tuvo que superar más adelante la expedición; los campos de turba(...) el día anterior ya había quedado demostrada la bondad del equipo radial y de su operador el suboficial Arata, que nunca fallarían. La temperatura minima en la noche fue de $0^{\circ}$.

El día 26, en Corrales de Marcou (campamento $N^{\circ}$ 2) se remodelaron las cargas en los caballos haciéndolas mas altas y delgadas para facilitar el transito por el bosque. Se viaja con 4 cargueros y 5 silleros. Una curiosidad es ver como los cargueros deben ir de cabestro, y frecuentemente este se amarra a la cola del caballo que le precede a la marcha. A poco de la partida (...) empezamos a subir una empinada cuesta en la picada del bosque. Esta es interrumpida por los troncos caídos en un bosque sobremaduro, lo que obliga continuamente a sortear los obstáculos desviándose a un lado o a otro de la picada, apenas reconocible (...) A no ser por el baqueano, en algunas ocasiones se habrían tomado equívocamente senderos de guanacos como la buena ruta (...) a cierta altura (600 a 700 m.s.m.)los árboles, que ya ofrecen el característico aspecto aparragado, desaparecen y se da comienzo a un ascenso lento por la ladera desnuda, hasta alcanzar la primera cumbre que llamamos Portezuelo Marcou (...) en ese punto una ruta arranca hacia La Paciencia en dirección suroeste, en tanto que la expedición debía tomar mas bien hacia el sureste en demanda del lago Deseado (...) la cumbre esta constituida por un afloramiento de roca, arenisca marina, del

37 Reproducido de Niemeyer, 1978.

38 Turba: Terreno pantanoso y fofo construido por la putrefacción de vegetales en ambiente húmedo. Entre los vegetales abundan los juncos y algunos criptógamas. (Niemeyer, 1978:5) cual se extrajo la muestra petrográfica №1 (...) A partir de este auténtico portezuelo prosigue una ascensión brusca por la ladera empinada (52 de pendiente transversal) hasta alcanzar los $920 \mathrm{~m}$ la cumbre del lago Deseado(...) desde ella se domina la mitad occidental del lago Deseado y una laguna que Oyarzún llama Chica, y que propuse se bautizara Suboficial Arata o simplemente Arata ${ }^{39}$. (...) el descenso es brusco. Dura dos interminables horas (...) al fin se alcanza la orilla norte del lago Deseado y por ella se sigue al ras del agua hasta su extremo occidental donde hay un lugar adecuado para campamento, al borde de la playa y en el margen del bosque (...).

El día siguiente estaba destinado a dar descanso a los animales en el campamento $N^{\circ}$ 3. Había abundante pasto en el área pantanosa entre el extremo oeste del lago y la laguna Arata. (...)Por primera vez los expedicionarios tomaron contacto con un fenómeno curioso; las represas construidas por los castores (Fig.25) (...) el valle plano y pantanoso, en el fondo de la depresión tectónica de la cual forma parte el lago Deseado, la laguna Arata y el valle La Paciencia que se extiende al oeste, está plagado de estas lagunas de castores, según Oyarzún. (...) en el lago Deseado se encuentra una gran cantidad de salmones o mejor dicho truchas asalmonadas, de carne rosada y de carne blanca; llegan a tamaño de 40 a $50 \mathrm{~cm}$. Tanto el suboficial Arata como Oyarzún proveyeron de carne de salmón desde el primer día que se tocó el lago. La forma de cocinarla fue variada, hasta de ceviche.

Aproveché de recorrer la ribera norte del lago que presenta numerosos afloramientos de roca correspondientes a sedimentos marinos (muestra petrográfica $N$ o) 2).

El día siguiente, 28, amaneció obscuro y amenazador (...) durante una hora y media seguimos por la ribera sur del lago, por la misma agua (...) dicha ribera es en gran parte abrupta y rocosa (...) Los troncos caídos en el agua dificultan enormemente el camino. Alcanzada la desembocadura del segundo río que desciende desde la falda del lago, debe enfilarse por una picada en el bosque

39 Lo que fue bautizado en el momento como laguna Arata corresponde al lago Despreciado. No se sabe con certeza si es que el nombre propuesto por Niemeyer llegó a figurar en algún mapa. 


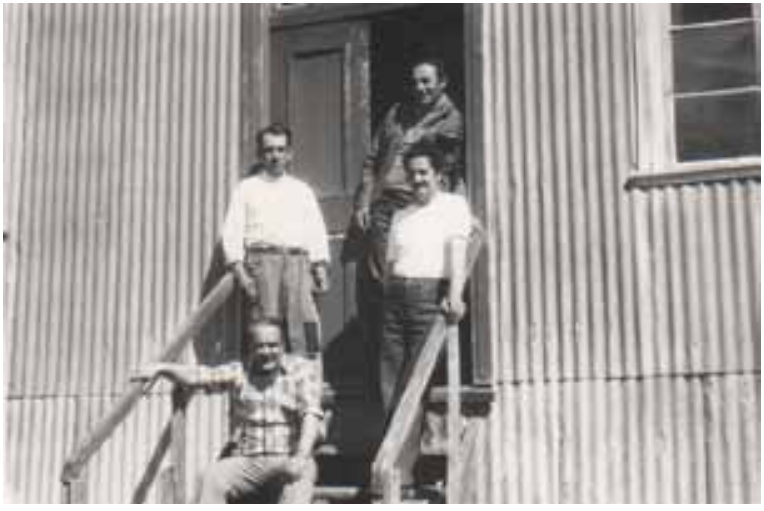

Fig. 23. Acceso a la cocina de Estancia Vicuña. Eduardo Larravide (sentado en la escalera) José Catalán (Hermano de Reinaldo Catalán, quien se encontraba trabajando en Vicuña, de pie a la izq.) Luis Arata (en la puerta) Arístides Vargas (de pie a la derecha)

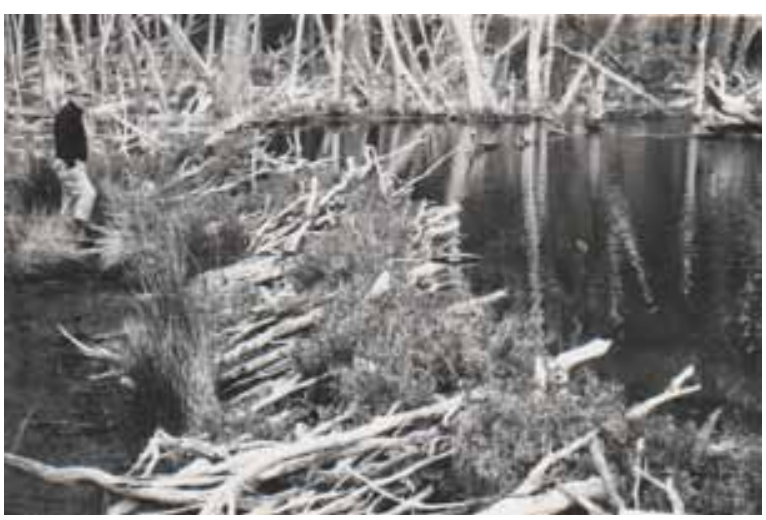

Fig. 25. Hans Niemeyer junto a una represa de castor en la cabecera del lago Deseado.

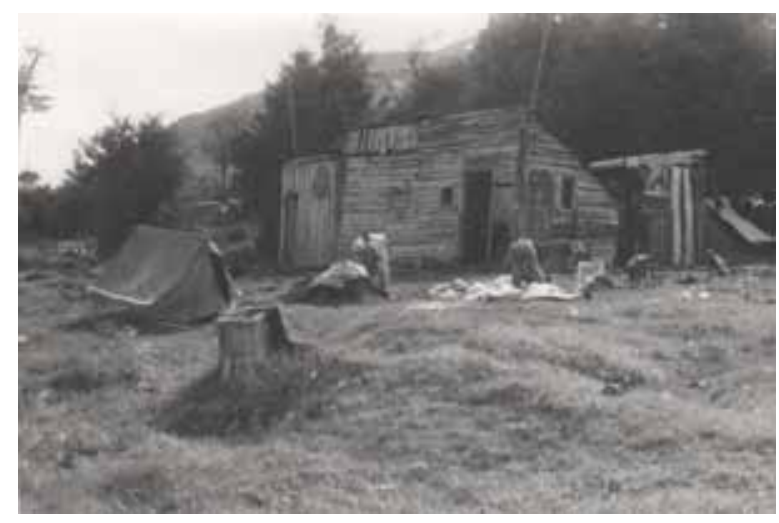

Fig. 27. Rancho Barrientos.

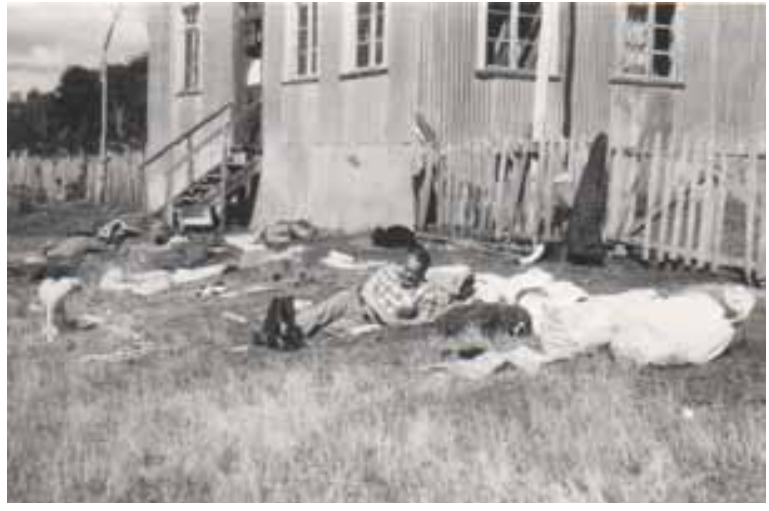

Fig. 24. Eduardo Larravide, descansando en Vicuña el día previo al inicio de la expedición.

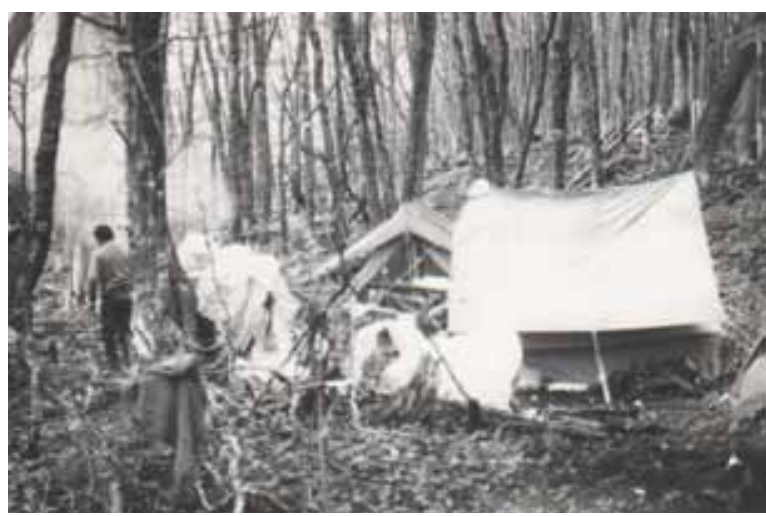

Fig. 26. Campamento en extremo occidental el lago Deseado.

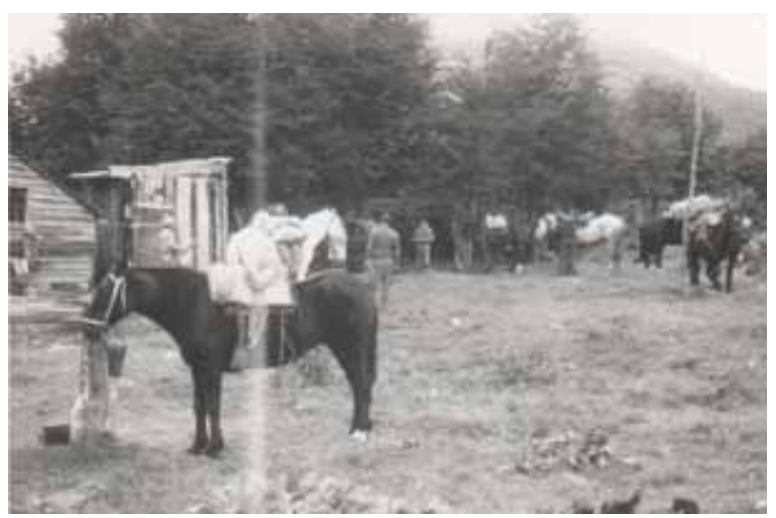

Fig. 28. Preparando partida del lago Fagnano. 
la que se inicia con una cuesta pronunciada. El bosque es más bien ralo, no tan tupido como el de la ladera norte del lago, pero el avance se ve dificultado a cada momento por palizadas caídas, subidas bruscas y fangales; estos últimos se han empeorado con la lluvia reciente (...) a las 4 PM llegamos a un claro en el bosque a orillas del río. Dicho río aparece innominado en las cartas oficiales y fue bautizado por nosotros en el momento como río Oyarzún, en homenaje al sacrificado arriero.

Más tarde supimos que era conocido como "río del Ejército" en carta de la ENAP. Aquí, a $670 \mathrm{~m}$. Se instaló el campamento NN4 llamado campamento de los Geólogos, puesto que allí estuvo su base algunos años una pareja de estos profesionales de la ENAP. Se conservan restos de su improvisado mobiliario. (...)

Paró la lluvia en la noche y el cielo apareció estrellado. Se acostaron los expedicionarios con la esperanza de ver sol al día siguiente. No fue así. Amaneció lloviendo. Tomamos la resolución de alistar las cargas y partir en demanda del lago Fagnano apenas amainara la lluvia. Sucedió al medio día. Desarmamos las carpas que es lo último en empacarse, e iniciamos el ascenso siguiendo aproximadamente el curso del río del Ejército (...) Tuvimos ante nuestro ojos el portezuelo en el cordón La Paciencia que debíamos trasponer para pasar de la cuenca del lago Deseado a la del Fagnano (Fig.14). El altímetro acusó 920 m.s.m. El descenso no es tan violento como el anterior al lago Deseado. Se sigue uno de los cañadones que conduce más directamente a la llanura norte del L. Fagnano (...) Sin embargo esta travesía no es tan larga y la llanura se presentó con vegetación muy rala debido a dos circunstancias; la explotación antigua de la madera por el aserradero que existió en Caleta María, al fondo del Seno Almirantazgo, perteneciente a la firma Campos, Marcou y Cía., y por un incendio relativamente reciente.(...) Habiendo salido del campamento de los Geólogos a las 13:10 hr, el arribo al rancho Barrientos (Fig.27), en la orilla norte del lago Fagnano lo hicimos a las 17:30 $h r$. En el rancho había fuego encendido y estaba habitado por dos trabajadores del señor Arturo Barrientos Leal, arrendatario de estos campos y habitante solitario de Caleta María.

El rancho de madera que constituyó el campamento $N^{\circ} 5$, estaba compuesto de tres cuartos, uno destinado a los aperos y a despensa. Otro, a cocina pero disponía de dos literas. El tercero era el dormitorio con tres literas. La cocina o estufa consistía en un tambor de 200 L. adaptado. Calefaccionaba bien la pieza. Aquí dormimos como se pudo.

El ánimo estaba bueno. Larravide y Arata se terciaron con los puesteros en una amena partida de truco. Poco antes Arata hizo una instalación del radio transmisor que le permitió tener la comunicación de la tarde bajo techo.

Continuó lloviendo por la anoche y amaneció lloviendo. Pero felizmente en las primeras horas de la mañana salió viento del oeste e hizo su aparición el sol (...) Sabíamos que en frente, en la ribera sur del lago Fagnano, en el borde oriente de la llanura aluvial del río Betbeder, se encontraba Reinaldo Catalán habitando en un rancho de madera en una pequeña ensenada del lago. Tenía prometido ${ }^{40}$ de antes servir de guía a la expedición en sus próximos pasos hacia el sur, de modo que se le impuso de la presencia de ella por la señal convenida de encender dos fuego al atardecer en la playa norte, frente al rancho $\mathrm{Ba}$ rrientos. Los prismáticos detectaban su presencia a través de los $3 \mathrm{~km}$. de separación que impone el lago. Para reforzar nuestra llegada, Arata disparó una ráfaga de fusil.

El día siguiente amaneció nublado y gris. El lago en completa calma. Según Oyarzún, el camino a Caleta María, localidad que forma parte de su maravilloso mundo inmediato, era fácil, sin turbas, sólo había que soportar un zambullón en la orilla del lago en un espacio de $10 \mathrm{~m}$. La caravana incrementada por los muchachos Ruiz ${ }^{41}$ y Maldonado (Fig.20) que bajaban a recibir ordenes de su patrón el señor Barrientos, se puso en camino a eso de las 10 1/2 AM. Se vadeó fácilmente el río Alonso

40 En enero de 1978 una comisión con el mismo fin se extravió en el Cordón La Paciencia, en las inmediaciones del lago Deseado, no pudiendo concluir con éxito su objetivo. En esa oportunidad Reinaldo Catalán no los pudo acompañar en la travesía ya que en ese momento se dirigía a Porvenir con sus vacunos. Al enterarse del fracaso de la expedición, Catalán deja de manifiesto en el retén de Pampa Guanaco que él esta dispuesto ayudar a cualquier comisión desde ese momento en adelante.

41 Sergio Ruiz Nahuelcar, oriundo de Chiloé, fallece trágicamente, a sus 36 años de edad, el 16 de noviembre de 1991 en la localidad de Cerro Sombrero, Tierra del Fuego (Chile) 


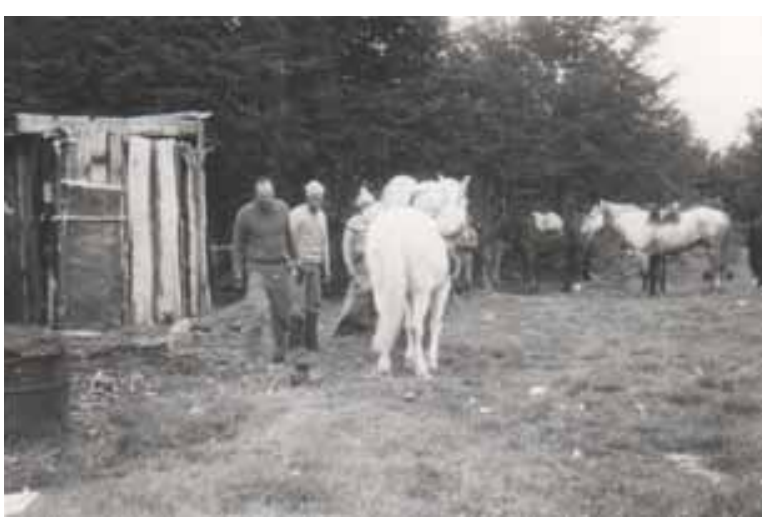

Fig. 29. Preparando partida del lago Fagnano.

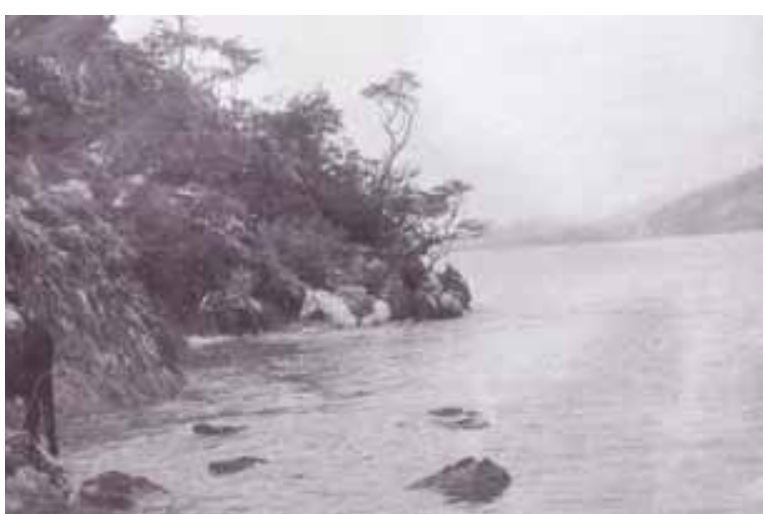

Fig. 31. Recorrido por la orilla norte del lago Fagnano.

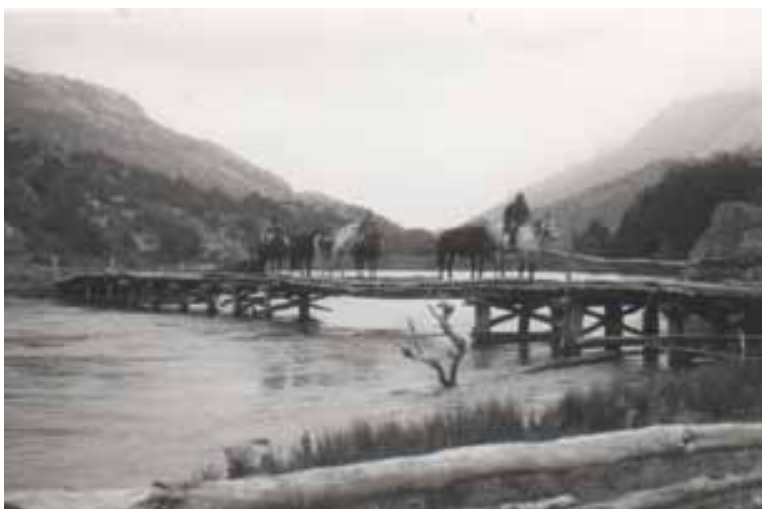

Fig. 33. Puente sobre el río Azopardo, a pocos kilómetros de su desembocadura.

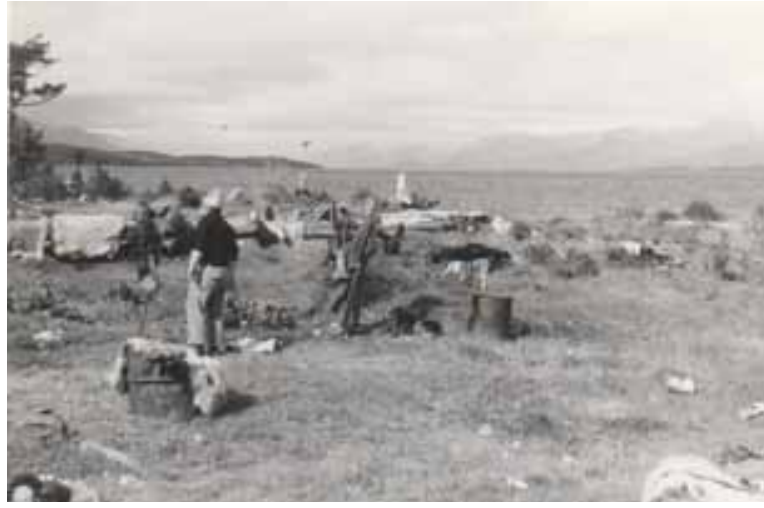

Fig. 30. Secando el equipo en la orilla norte del lago Fagnano.

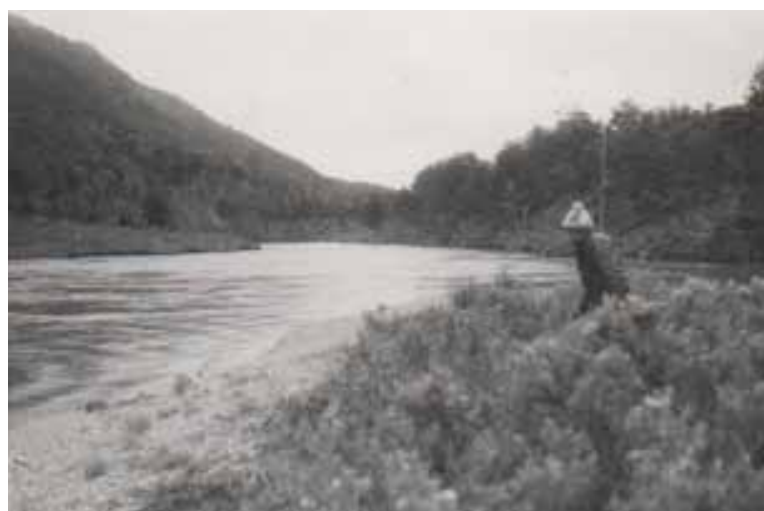

Fig. 32. Río Azopardo, visto desde su nacimiento aguas abajo.

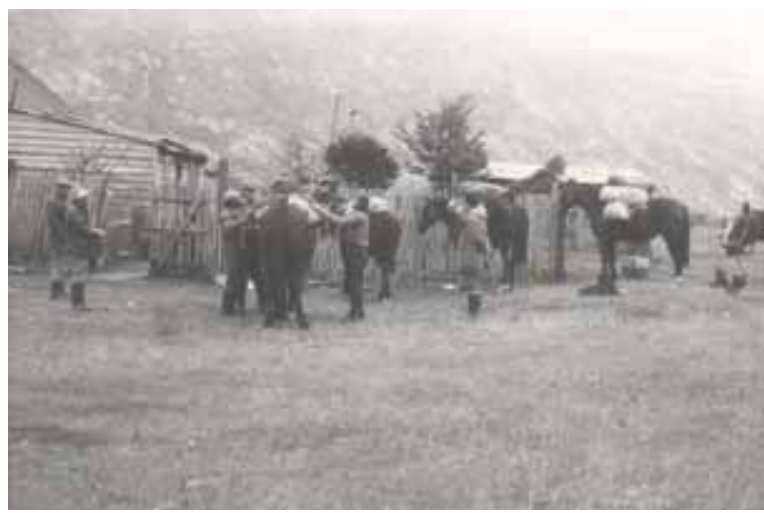

Fig. 34. Preparando partida de Caleta María. (De izq. A der.)Arturo Barrientos, Eduardo Larravide, Francisco Oyarzún, Luis Arata, José Maldonado, Arístides Vargas. 
y marchó por la orilla norte del lago Fagnano por espacio de unos $4 \mathrm{Km}$. y duración de $1 / 2$ hora con el agua quieta, casi hasta las monturas (Fig.31). El tramo más hondo, que era el temido anunciado por Oyarzún, se pasó sin que los caballos nadaran.(...) llegado al desague, que es el nacimiento del río Azopardo, el más caudaloso de la zona, emisario del lago Fagnano o Cami, se estimó su ancho $m$. y caudal en $150 \mathrm{~m}$ 3/s. Allí se forman algunos remolinos y contracorrientes que dificultan su cruce a nado aunque en ciertas ocasiones $R$. Catalán lo ha atravesado con vacunos, cuando tenía en buenas condiciones un bote que hoy esta roto $y$ abandonado en la playa. Continuamos en demanda de Caleta María. (...) En un punto intermedio de la ruta, mirando hacia atrás se divisa el lago y hacia delante el fondo del seno Almirantazgo.(...)

La ladera opuesta, la que flanquea por el sur al río, se ve más baja y plana, aunque más boscosa y turbosa, además que la escinden algunos cañadones se ve topográficamente más favorable para construir un camino de unión entre el lago Fagnano y el seno Almirantazgo. A unos tres kilómetros del mar el sendero desciende y el río Azopardo se cruza por un puente de madera antiguo, (Fig.33) en regular estado, le faltan cepas centrales. Luego se cruza el río Mascarello que proviene de una abra profunda del flanco sur y es de reducido caudal $(3 \mathrm{~m} .3 / \mathrm{s})$, para entrar de lleno a la gran llanura de Caleta María, en cuyo inicio hay una cancha de aviación de $800 \mathrm{~m}$. de longitud que podría rehabilitarse con pequeño trabajo. En el extremo sur de la extensa playa que constituye el fondo del seno Almirantazgo se levantan las construcciones de

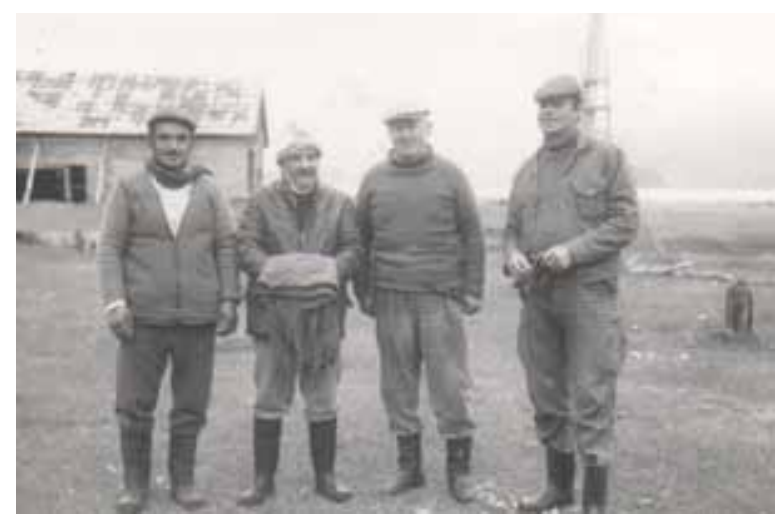

Fig. 35 (de izq. a der.) Reinaldo Catalán, Eduardo Larravide, Arturo Barrientos, Luis Arata en Caleta María.
Caleta María: un galpón muy grande en ruinas, varias casas pequeñas y una más grande que es la que habita don Arturo Barrientos. Estas construcciones formaban parte de la antigua estancia Almirantazgo y después, de las instalaciones del aserradero que por unos años mantuvo la firma Campos y Marcou y Cía. Poco antes de arribar a ella debe vadearse el río Fontaine de respetable caudal y de aguas blanco - lechosa por originarse en ventisqueros colgantes en un cañadón profundo que viene directamente del sur.

Don Arturo Barrientos brindó hospitalidad en su casa y proporcionó carne, alimento que ya venía escaseando. Se había llegado, al fin, a Caleta María, la que constituyó el campamento № 6. Y en realidad, un grupo de casas algo arruinadas en el paisaje limpio y fresco del seno Almirantazgo, era como haber vuelto un poco a la civilización. (...)

Al día siguiente enviamos a unos de los puesteros $^{42}$ con un mensaje $e^{43}$ a Reinaldo Catalán

$42 \mathrm{Al}$ puestero que se envió con el mensaje (cartas) para Catalán fue José Maldonado M. (1955), apodado El Rubio (Fig.20), natural de Puerto Varas. José Maldonado llegó a Magallanes en 1975, sin otro motivo que la aventura misma. En este mismo año se desempeñó como trabajador en el rancho Sutivan, ubicado en isla Riesco, comuna Río Verde. Por medio de su patrón, Patricio Yutronic, conoce a Arturo Barrientos Leal, arrendatario de Caleta María, para quien trabajaría desde 1976 hasta 1978. Desde entonces El Rubio ha recorrido gran parte del sur de la isla ya sea como baqueano, bagualero, cazador de castores, campañista, puestero. Desde 1997 y hasta la fecha, José Maldonado se desempeña como trabajador en la estancia Tres Hermanos ubicada en las inmediaciones de la desembocadura del río Marazzi en bahía Inútil, Tierra del Fuego (Chile).

43 Ver apéndice II y fig. 48y 49.

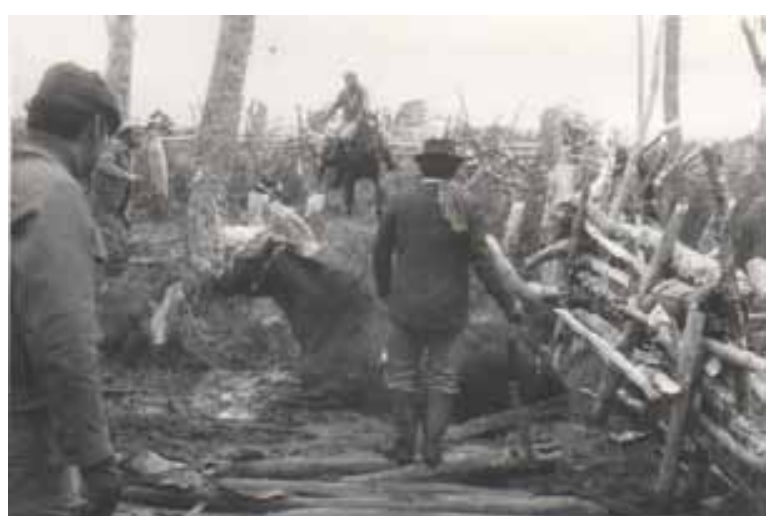

Fig. 36. Carguero empantado en los turbales del Betbeder, Reinaldo Catalán montado en caballo. 


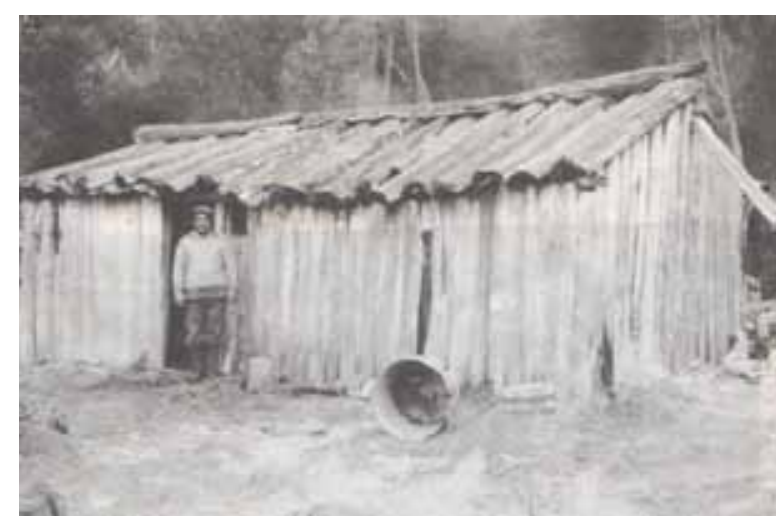

Fig. 37. Reinaldo Catalán en su rancho en la orilla sur del lago Fagnano.

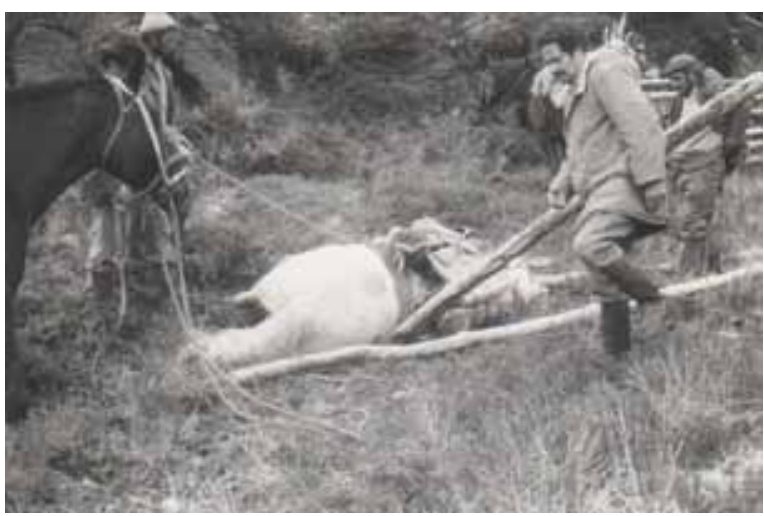

Fig. 39. Cuyuyo empantanado en los turbales del Betbeder. Extracción con sistemas de palancas. (de izq. a der.)

Francisco Oyarzún, Arístides Vargas y Reinaldo Catalán.

pidiéndole que sirviera de guía a la expedición en lo sucesivo. Los conocimientos de Oyarzún terminaban en su Caleta María (...)

(...) Pasado el medio día -cuando ya nos poníamos impacientes- llegó Reinaldo Catalán acompañado de Maldonado y de su ayudante Víctor Garay. Catalán expresó que con mucho gusto nos llevaría hasta donde él conocía del camino a Yendegaia y que el resto lo exploraría, pero que de todos modos se proponía llevar la expedición sin novedad a su destino. Lo hacía desinteresadamente. Con él y su ayudante ya eran tres personas avezadas en el manejo de los animales, lo que aumentaba las expectativas del éxito.

El 6 de marzo reinaba gran agitación en Caleta María desde temprano (Fig.34). A las 10 1/2 se ponía en marcha la caravana de siete personas montadas: Niemeyer, Larravide, Arata, Vargas,

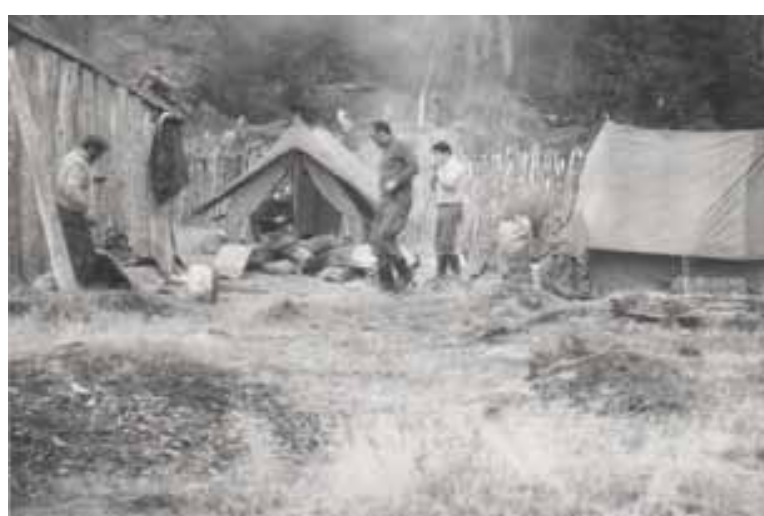

Fig. 38. Campamento Catalán (izq. a der.) Reinaldo Catalán, Hans Niemeyer (sentado), Luis Arata y Víctor Garay.

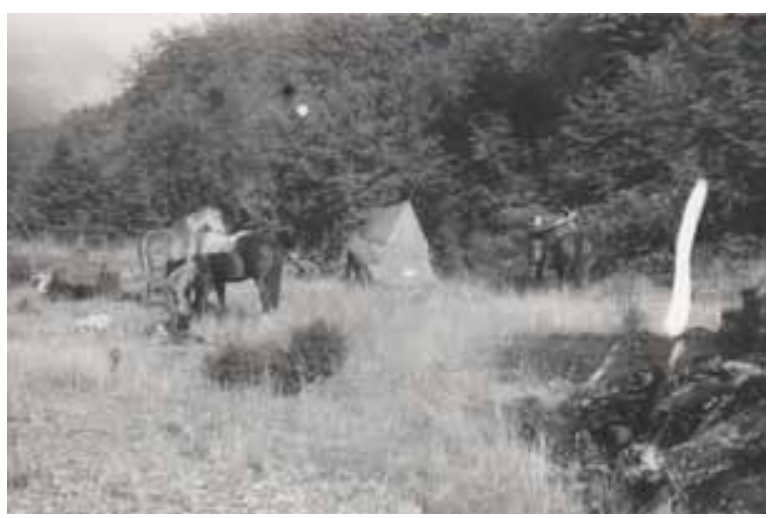

Fig. 40. Campamento en el valle Betbeder.

Catalán, Oyarzún y Garay, cuatro cargueros y cuatro perros pastores de Catalán. Vadeamos el río Fontaine y antes de llegar al puente sobre el Azopardo tomamos la ladera sur de éste para continuar por ella hasta su nacimiento y vivir una buena odisea. La turba es cosa seria. Los animales se metían en ellas hasta los ijares. Sin embargo los animales de Catalán tenían costumbre en esta clase de terreno y no sufrían tanto. Cuando un sillero se empantanaba había que saltar rápido para que al echarse de lado no aplastara la pierna del jinete. La yegua que yo montaba, la "reservada" como la llamaba Oyarzún, adquirió particularmente esta maña. Los cargueros debían ser liberados de su carga para que salieran del pantano.

Bordeamos el lago Fagnano por su ribera sur, por el agua, y luego nos internamos por el borde oeste de la llanura del Betbeder. Debimos pasar por 
un arroyo al cual tienen represado los castores. El agua peraltada mojó un envaralado que tenía hecho Catalán y los palos redondos y sin amarras estaban resbalosos. Pasan tres caballos y al que sigue, el más fuerte de los cargueros se le resbalaron los palos y quedó con las patas hundidas entre ellos colgando de la barriga. Hubo que quitarle la carga. En un intento por salir también las manos se le metieron entre los palos. Hubo entonces que correr para el lado algunos de los palos, amarrarlo a la cola y del cabestro y tirarlo con otros dos caballos. Así después de muchos esfuerzos, salió arrastrado de lado (Fig. 36). Catalán entre tanto había desaguado algo la poza rompiendo la represa. Dice que muchas veces ha hecho esa operación y que al día siguiente amanece reconstruida. Sobrepasado el puente lo que viene es a travesar los turbales de la llanura al oeste del Betbeder. Dura tarea. Hay que ir a pie con los caballos de tiro. Un caballo, el "Cuyuyo" cayó de tal manera que no podía salir de ella. Se recurrió por primera vez al arbitrio de poner en su costado a lo largo dos troncos que sirvieron de apoyo para dos palancas que se metieron por debajo de la barriga y del pecho del animal. No hubo caballo que no se empantanara en esta penosa travesía de unos 700 metros. Fueron algunas horas de lucha y angustia. El tiempo estaba malo y de vez en cuando caía un chubasco leve. Tuvimos que transportar la mayor parte de los bultos al hombro. Llegamos así a la orilla del río Betbeder. Este venía de crecida de aguas turbulentas y turbias. Días antes las aguas habían destruido una pasada provisoria construida con troncos por Catalán. El suboficial Arata se adelantó en vadear el río con su caballo

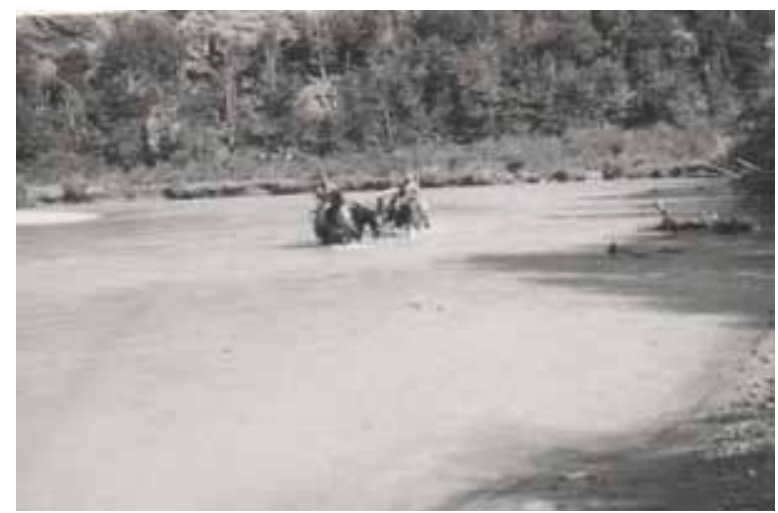

Fig. 41. Los baqueanos Reinaldo Catalán y Francisco Oyarzún vadeando el río Lapataia. grande para estar a tiempo en su comunicación radial de la tarde.

A continuación se fueron juntando en la orilla izquierda todos los miembros de la expedición y el resto de los cargueros. Pasó primero Catalán con un carguero indicando la mejor ruta contra la corriente; lo siguió Garay y Oyarzún con sendos cargueros al cabestro. Luego pasó el resto con los caballos más chicos. Parecía a momentos que el agua los iba a arrastrar, pero se afirmaban. Catalán estaba presto con su lazo para actuar por si algo sucediera. El agua superó las botas de goma, y nos mojó hasta bien arriba las piernas pero al fin era un detalle sin importancia al lado del peligro que enfrentábamos. En una media horas todos nos encontrábamos reunidos en los corrales de Catalán, sobre piso firme en la ribera derecha del Betbeder donde había hecho Arata la instalación de la antena.

Decidimos, sin embargo, buscar mejores condiciones de alojamiento y cabalgar algo menos de una hora hasta llegar al rancho de madera de Reinaldo Catalán (Fig.37), único poblador de toda esta región al sur del lago Fagnano. Estaba lloviendo. Se cambiaron dos caballos que presentaban problemas para continuar, por otros que ofreció Catalán. Uno de ellos era el famoso Panchito que estaba aún en estado semiarisco, costaba montarlo y ya había hecho dos o tres pesadas bromas.

Amaneció amenazante al día siguiente. Así y todo, chispeando a ratos, se decidió hacer las cargas y se abandonó la orilla del lago Fagnano a las 12:40 hr para remontar el margen derecho del Betbeder. (...)

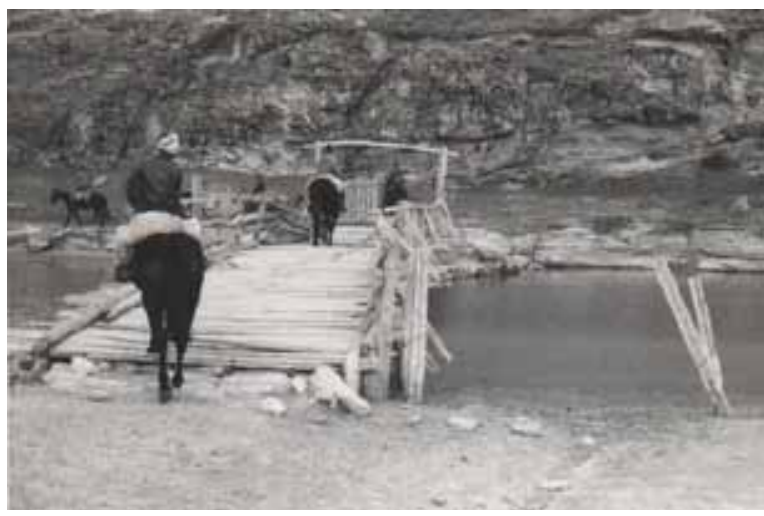

Fig. 42. Llegando a estancia Yendegaia. 


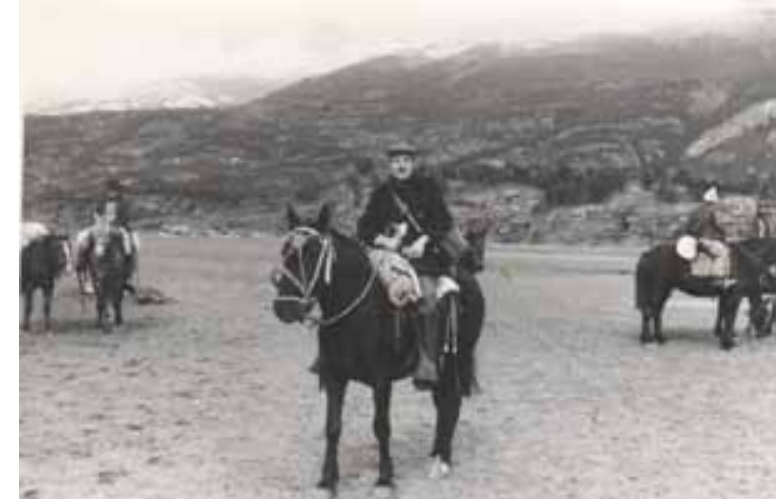

Fig. 43. Hans Niemeyer.

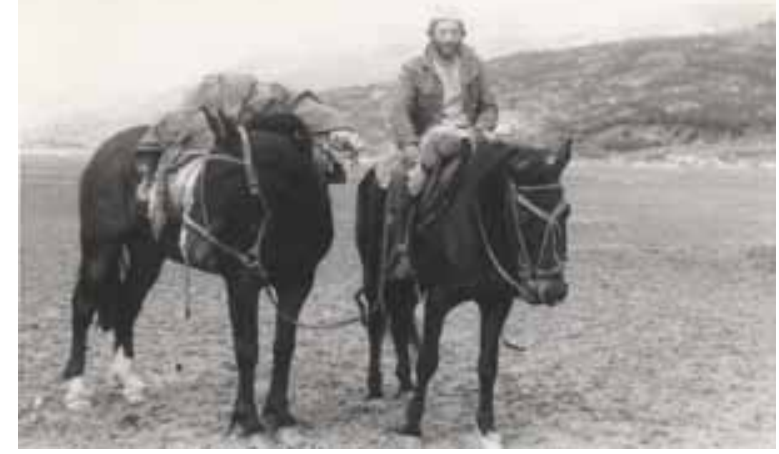

Fig. 45. El baqueano Francisco Oyarzún.

A poco de sobrepasar los corrales de Catalán, se llegó de lleno a un turbal de unos $300 \mathrm{~m}$ de largo. La mayoría desmontó para pasar los caballos al cabestro. Los cargueros sufren continuamente. El caballo Cuyuyo ha perdido la voluntad de pararse (Fig.39). Hay que descargarlo y sacarlo mediante palancas de troncos (...) y parecía que no salía y que habría que sacrificarlo. Pero repitiendo la operación de salvataje se logró zafar.(...) a poco andar (...) el Cuyuyo resbaló y cayó a las remolinadas aguas del río con la carga de las carpas. Se dio una vuelta en el torbellino, pero se pudo parar y salir al otro lado. En esta vuelta se perdió un hacha grande que se consideraba indispensable para abrirse camino en el bosque. Quedaban sólo dos hachas de manos. (...)

Al fin, después de dura jornada, se arribó a un punto a orillas del bosque y de una pastosa

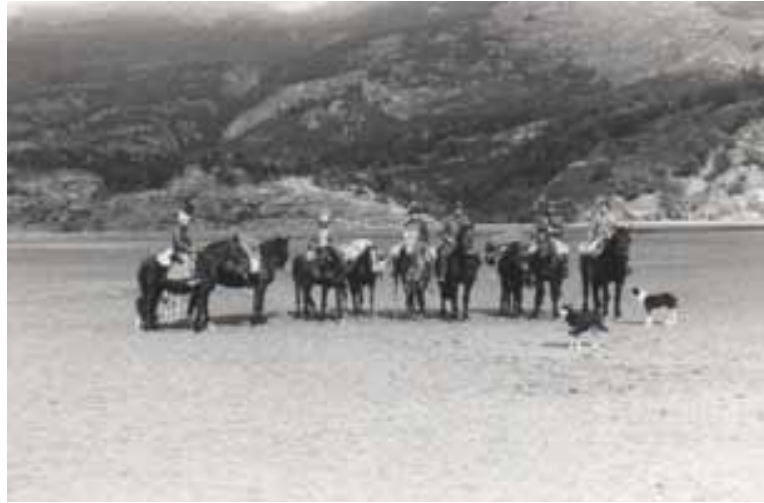

Fig. 44. Arribo a la estancia Yendegaia. (de izq. A der.) Eduardo Larravide, Francisco Oyarzún,

Víctor Garay, Luis Arata, Reinaldo Catalán,

Arístides Vargas y los perros de Catalán.

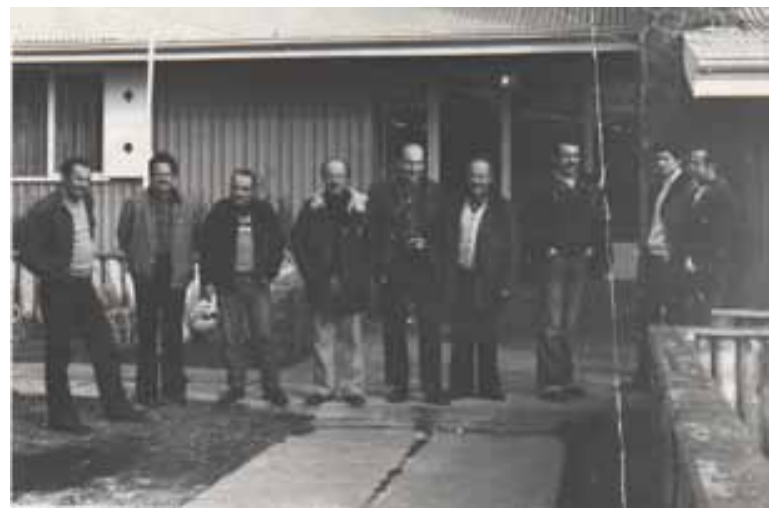

Fig. 46. La comisión en Puerto Williams (de izq. A der.) Luis Arata, Arístides Vargas, Eduardo Larravide, Hans Niemeyer y los ingenieros Izquierdo y Valenzuela.

vega riberana del río Betbeder, a $200 \mathrm{~m}$ aguas arriba de la junta de los dos afluentes formativos de dicho río. Se instaló aquí el campamento № 8 (Fig.40) el día 8 de marzo (...)

De las dos "patas" que forman el río, según Catalán la ruta debe continuar por la más oriental, y la senda deberá ser abierta. La otra "pata" conduce a paredones rocosos a piques con ventisqueros colgantes.

Llovió toda esa noche y continuó lloviendo en el día siguiente, que por suerte estaba destinado a dar descanso a los caballos que en los dos días anteriores habían sufrido mucho. Casi todos los cargueros y algunos silla tenían averías en el lomo y la cruz. (...) Amainó la lluvia al medio día y Catalán salió a reconocer la ruta (...) Catalán regresó a eso de las 9 de la noche después de efectuar trabajos de despeje y romper diques de castores. 
(...) A través de la radio, se envió desde aquí un mensaje a radio Presidente Ibáñez para que ésta a su vez, en la hora diaria de mensajes pidiera que un hombre de la estancia Yendegaia saliera al encuentro en el valle Lapataia y nos indicara los vados (...) En la comunicación de ese día se empezó hablar del rescate, el que se programaba en Yendegaia mediante un cutter.

El día 10 amaneció hermoso y pronto calentó el sol (...) a las 10 1/2 se abrió la marcha remontando el brazo más oriental del río Betbeder, tras haber cruzado el otro a cuyas orillas se había levantado el campamento. El Cuyuyo fue abandonado a su suerte en medio de la llanura pastosa y las cargas redistribuidas.(...) Después de pasada una llanura en el brazo del Betbeder toma dirección E-O, se entra nuevamente al bosque y Catalán aconseja detener la marcha aquí y establecer el campamento № 9. Es apenas la una de la tarde y todos tenían los bríos y los ánimos para continuar la jornada. Pero Catalán sabía lo que hacía, según se vio al siguiente día. El campamento propuesto era el último punto con pasto antes de traspasar el cordón de cerros que separa la cuenca del Betbeder de la del río Lapataia, y era preferible trasponerlo de un viaje porque la subida inicial requería de mucho esfuerzo. La tarde fue empleada en reparaciones de equipo para lo cual Eduardo Larravide había provisto de todo lo necesario; leznas, cáñamo encerado, remaches de cobre con sus arandelas, etc. Se hacía sentir la carencia de carne. Catalán hizo un largo reconocimiento y llegó con buenas noticias.

El sábado 11 fue un día decisivo para el éxito de la expedición.(...) La caravana se pone en camino a eso de las 10 1/2 AM. Sale pronto del bosque y luego atraviesa un turbal de poca monta, pero suficiente para que uno de los caballos, muy debilitado, se empantane y haya que descargarlo. Se entra luego a una nueva mancha de bosque donde hay que ir retirando ramas, pasando chorrillos "malos" y sorteando los "aparragados". Salido de él se empieza a subir por un filo rocoso con grandes bloques de granito, peligrosos para las patas de los caballos de tiro por un pedrero granítico. Se avanza y descansa a ratos. La caja con el equipo fotográfico pesa cada vez más. El tiempo es favorable y lo será en lo sucesivo casi sin interrupción. Se alcanza un lugar de descanso en el faldeo junto a un riachuelo. Este es afluente del brazo del Betbeder que se viene siguiendo y nace de una hermosa laguna al pie de un ventisquero colgante. Dicha laguna había sido visitada por Catalán en sus andanzas de la víspera. El sol hace más relevante la belleza de los hielos tanto en el ventisquero como en los pequeños témpanos que flotan a la deriva en la laguna. Desde aquí ya se puede divisar bien el camino a seguir para trasponer el cordón que se tenía por delante.(...) La cumbre es una especie de meseta alta poblada de lagunas y compuesta de pizarras y esquistos. Catalán viene de a pie portando en su caballo una bolsa pesada para aliviar a otra cabalgadura. El suboficial va adelante con el fusil preparado, ya que es seguro el encuentro con algún guanaco. Los demás siguen a regular distancia. Traspuesto el portezuelo, Arata divisa un piño de vacunos y llama desde abajo a Catalán. Después se supo que la consulta era a cual animal del piño disparaba. Mató un ternero sin que escucháramos el disparo, y el resto pasó corriendo hacia un portezuelo secundario. Visto esto por Oyarzún y Garay, abandonaron sus cargueros en media ladera del descenso y bajaron al galope a interceptar al piño con los perros. Estos, hambrientos como estaban, agarraron una vaquilla y la volcaron sobre un terreno turboso. Por una parte Arata y Catalán descueraban el ternero, y por otra parte, Oyarzún y Garay hacían lo propio con la otra, ignorándose mutuamente lo sucedido. El resto de los expedicionarios cabestrean los cargueros abandonados y todos al fin se juntaron para armar el campamento № 10. (...) Aquí todos pudieron saciar su ansiedad de carne.

El portezuelo que se acaba de trasponer tiene una cota de alrededor de $770 \mathrm{~m}$ y desde el se domina hacia el oriente la laguna Lovenborg (o Lowenborg) y el valle superior de su emisario el río Rojas $^{44}$, al cual sirve de telón de fondo la Sierra

44 El lago Lowenborg y río Rojas fueron bautizados, durante su expedición a la zona, por el botánico Carl Skottsberg en marzo de 1908, el primero en honor al Cónsul General de Suecia en Chile, el Sr. A. Lowenborg quien en esa fecha viajó a Punta Arenas para darles la bienvenida y brindar toda la asistencia que pudieran necesitar para tratar con las autoridades chilenas y el segundo en honor al Vice almirante A. Rojas de Punta Arenas, quien puso a disposición el pequeño vapor "Huemul" para el traslado entre Punta Arenas y seno Almirantazgo de la expedición. Ver Skottsberg (2004:45-69), capítulo 3 "En Tierra del Fuego" 


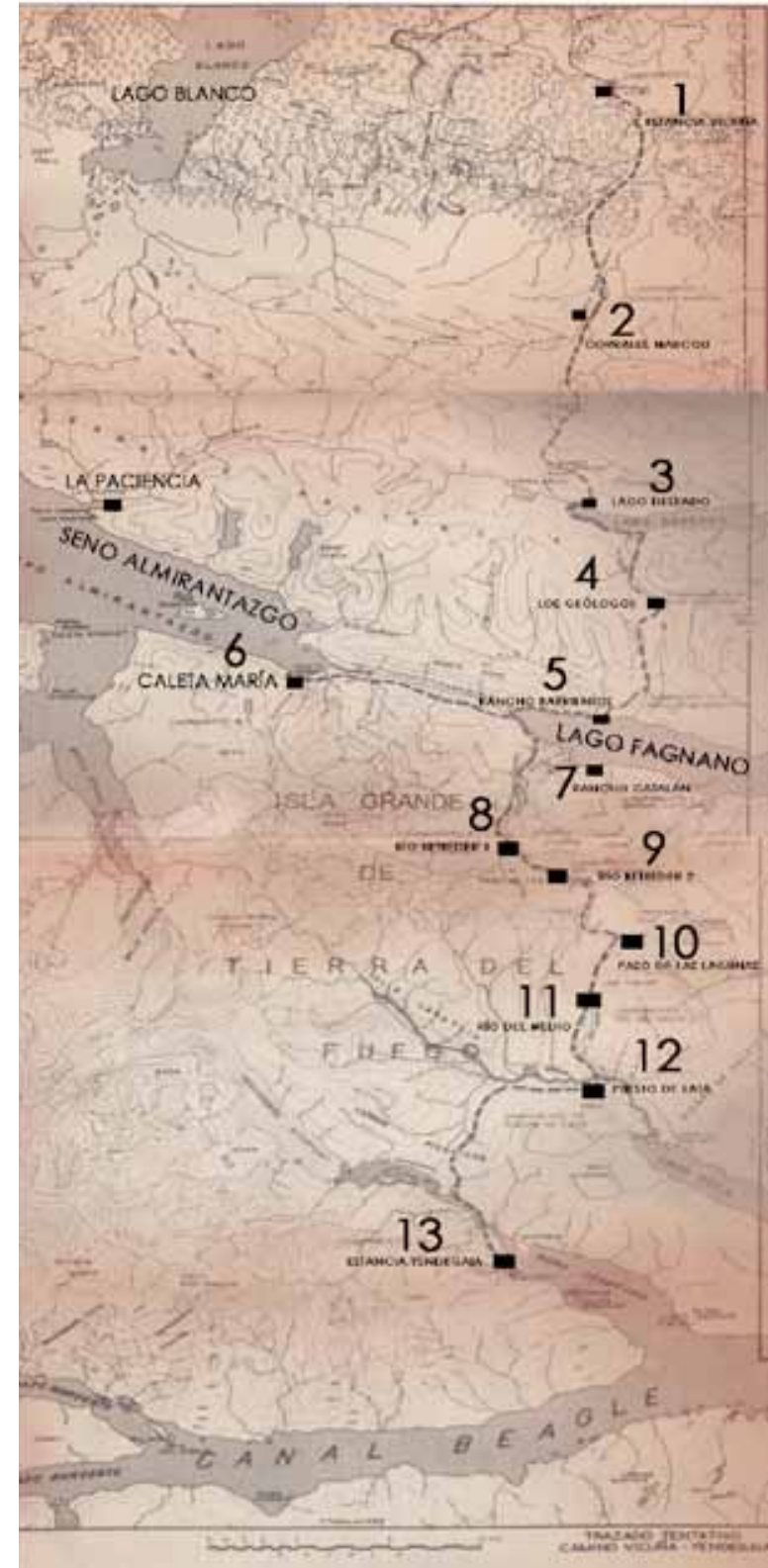

Fig. 47. Mapa original publicado en MOP,1978.

Para ayudar en su comprensión y legibilidad el autor reescribe el nombre y números de los campamentos realizados por la comisión expedicionaria.

Valdivieso. En esta resalta un cerro de cima plana y paredes acantiladas al cuál Catalán distingue con el nombre de cerro Cuadrado. Así se ha seguido denominando en las fotografías.

El portezuelo - bautizado por Skottsberg con el nombre de Paso de las Lagunas en 1908, debido

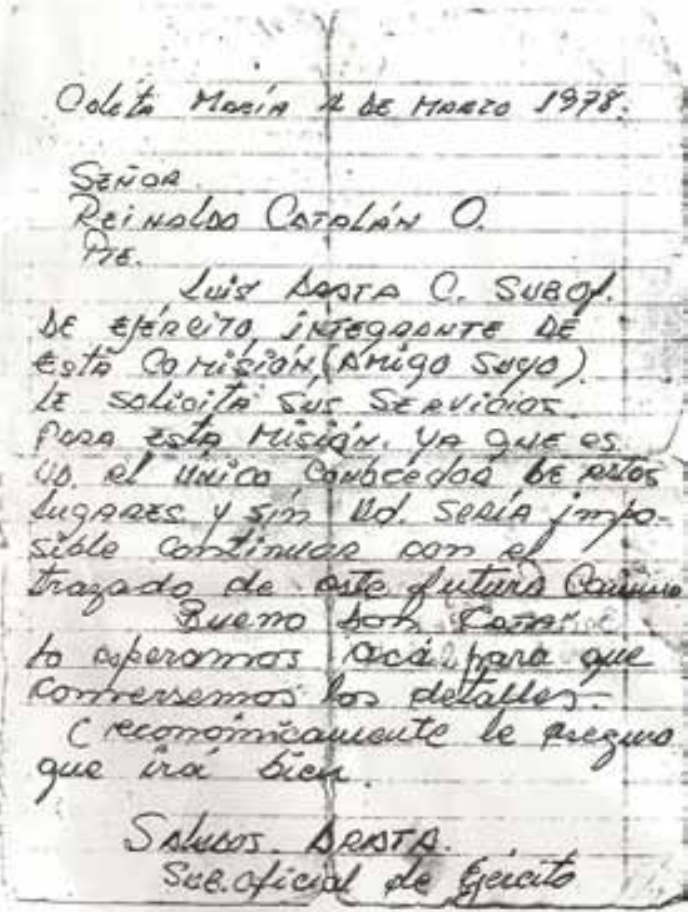

Fig. 48. Carta escrita por Luis Arata dirigida a Reinaldo Catalán (Gentileza de Reinaldo Catalán).

a los estanques de su cima, según se supo después - estaba libre de nieve y sólo algunos manchones quedaban aislados en hondonadas protegidas, hacia flancos.(...) Un portezuelo secundario constituye la divisoria de agua entre la vertiente hacia el río Rojas y la del valle que se observaba.(...) Bien abajo en este valle se veía el resto del piño de vacunos que se había librado de la cacería, el cual pasó por el portezuelo secundario. No cabía duda que ésta era la ruta que la expedición debía seguir. En efecto, al día siguiente se puso en marcha hacía ese paso secundario. (...) Al traspasar el portezuelo secundario, de 700 m.s.m, se encontró no menos de media docena de cóndores.(...) Por alguna ladera debían pasar los vacunos que pertenecían, sin duda, a la estancia Yendegaia.(...) Se dividió la expedición en dos fracciones. Una con el arriero Oyarzún subió a explorar la ladera izquierda, y Catalán la ladera derecha. (...) Oyarzún regresó con malas noticias. Catalán por su parte había dicho que volvería alrededor de las 4 PM. (...) Era preferible acampar y definir bien la ruta (...) Llego Catalán con buenas noticias. Con poco trabajo se podría mejorar una picada en el bosque y proseguir por 


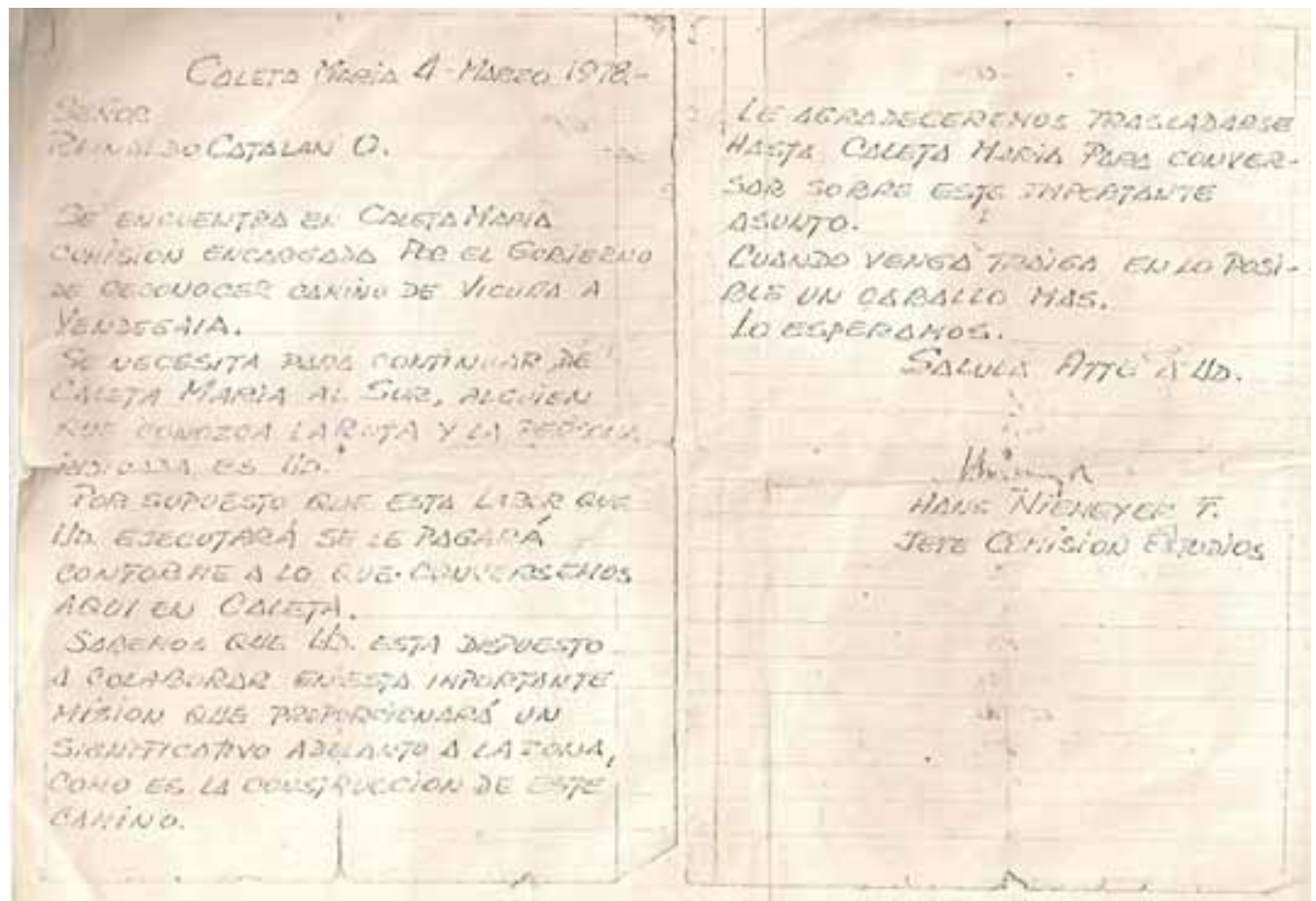

Fig. 49. Carta escrita por Hans Niemeyer dirigida a Reinaldo Catalán. (Gentileza de Reinaldo Catalán).

la ladera derecha. El había llegado hasta un claro que le permitió ver el río Lapataia y al otro lado, una casa, seguramente un puesto de la estancia cuyos terrenos se pisaba.

Al día siguiente, lunes 13 de marzo, el pasto amaneció blanco. (...) A las 11 hr estuvo en marcha la expedición. (...) Al fin estuvieron todos en la orilla izquierda del río Lapataia y había que vadearlo (Fig.41). Garay resueltamente busca el camino con su caballo tordillo, bastante fuerte. Detrás sigue el resto. Los cargueros son los últimos en pasar. Tampoco aquí nadaron los caballos. En cosa de minutos estaban todos en la casa, que se encontraba abandonada. Se trata de una casa recubierta de lata, ahí su nombre de Puesto de Lata, según se supo más tarde.(...) Todos alojaron aquí excepto Niemeyer que armó su carpa en el prado, detrás de la casa. En comunicación radial de esa tarde se supo que el ingeniero Hugo Valenzuela estaba en Punta Arenas preocupado del rescate de la expedición y que el día siguiente un avión dejaría caer algunos víveres pedidos, sobre el prado de los corrales.

El día siguiente estuvo destinado a dar descanso a los caballos y a la espera del avión.
Sin embargo, en la primera comunicación de la mañana se pidieron informes sobre la cancha de aviación de Yendegaia ${ }^{45}$. Arata se ofreció para avanzar hasta la estancia e informar sobre este asunto. Catalán salió temprano a reconocer ruta. (...) desafortunadamente el tiempo estuvo variable, con nublados y chubascos que venían del oeste, desde el fondo del valle de Lapataia. Tal vez por esta causa el anunciado avión no vino.(...) Arata y Catalán venían juntos desde la orilla izquierda del río Yendegaia. El río con marea alta no da vado y no hubo persona alguna que apareciera desde las casas principales (...) las noticias sobre la ruta eran halagadoras. Aparte de pasadas malas en pequeñas manchas de turba o en chorrillos pantanosos, el resto de la huella transcurría como en un parque.(...) El mayor escollo lo ponía el vado del río Yendegaia, pero ya habría manera de superarlo. (...) En la comunicación de la tarde se supo que Hugo Valenzuela y Nicolás Izquierdo se habían embarcado en la barcaza Orompello de la Armada

45 Esta cancha de aterrizaje fue inaugurada el 20 diciembre de 1945. Consultar: "La Fuerza Aérea a establecido una cancha de aterrizaje en Yendegaia. El Magallanes.14 de enero de 1946 pág. 6. 
Nacional, la que en definitiva haría el rescate de la expedición al atardercer del día jueves.

El miércoles 15 de marzo la expedición hizo abandono del Puesto de Lata a las 8:50 $h r^{46}$ y recorrió el cañadón que conducía al valle del río Yendegaia. Tal como lo había anunciado Catalán, salvo pequeños escollos en los comienzos, había después una huella bien definida que se internaba en los bosques de fagáceas "como en un parque".

Al poco salir al valle de Yendegaia, se dejan atrás los restos de un aserradero, donde hay un locomóvil arruinado y cientos de "vigas" en posición de ser aserradas. Según se supo, este aserradero trabajó hasta 1966.

Pasado el medio día llegó la expedición a topa con la ribera izquierda del río Yendegaia. Felizmente la marea estaba baja. Garay nuevamente se arriesgó en las aguas turbías del río, a quien siguió el resto. Se vadeó sin contratiempo alguno. El valle es ancho y plano. Se atraviesa en menos de una hora la llanura aluvial, completamente plana, y se pasa un arroyo por un puente de madera en uso (Fig. 42). Al fin detrás de un cerrito costero, en el rincón sudoeste de la bahía se levantan las casas e instalaciones de la estancia Yendegaia de propiedad del señor Miguel Serka.

Sale al encuentro don Santiago Navarro, hombre de confianza encargado desde hace más de treinta años de la estancia. Dice que había escuchado el mensaje transmitido por la radio Presidente Ibáñez pero que no había podido cumplirlo porque el río no daba vado y que precisamente es ese mismo instante salía al encuentro de la expedición. (...) era el campamento № 13 , el último. La comunicación de la tarde confirmó el rescate en barcaza. (...)

En la tarde Niemeyer salió a tomar fotografías de la bahía Yendegaia desde un cerrito costero y aprovechó de hacer una herborización destinada como siempre al Herbarium Gunckel.

El jueves 16 por la noche se haría el rescate. Niemeyer aprovechó el tiempo para hacer un reconocimiento al valle Yendegaia.(...). Decide regresar en tres horas de caminar. De allí en adelante todo giró alrededor de la retirada: lavarse, arreglar

46 La hora fue impuesta por Catalán la noche anterior para lograr cruzar el río Yendegaia con marea baja. bultos, cancelar a los baqueanos ${ }^{47}$, disponer el regreso de los animales etc.(...) ya había anochecido cuando apareció la barcaza a eso de las 10 de la noche (...) En menos de media hora estaban todos embarcados a bordo saludando a los oficiales y a los ingenieros Izquierdo y Valenzuela. Una grata sorpresa fue encontrar a bordo al explorador de Aysén don Augusto Grosse quién hacía una gira tomando fotografías. Para no llegar de noche la barcaza disminuyó el andar y así amaneció frente a Puerto Williams el viernes 17 de marzo. De allí la expedición fue trasladada en un avión de una empresa particular a Punta Arenas.

\section{CONCLUSIONES DE LA EXPEDICIÓN}

La expedición demostró que el camino reconocido entre Ea. Vicuña y Ea. Yendegaia, llamado troncal, es físicamente factible de ejecutar ya que no se presentan obstáculos geográficos insalvables. Tendría una longitud de $138 \mathrm{Km}$ y un costo por concepto de obras de aproximadamente SUS 12.000.000 (doce millones de dólares), lo que arroja un costo estimativo por $\mathrm{km}$ de 86.100 dólares.

El camino acorta la distancia entre Porvenir y Yendegaia en $130 \mathrm{~km}$, en comparación con la longitud de la vía marítima, como asimismo considerablemente el tiempo de traslado.

El camino adoptará aproximadamente la ruta seguida por la expedición de febrero - marzo 1978, con la salvedad que el camino llamado troncal deberá cruzar el río Azopardo en su nacimiento mediante un puente de madera. Desde el podrá salir un ramal secundario que conduzca al fondo del seno Almirantazgo, a Caleta María ${ }^{48}$.

$\mathrm{El}$ pretendido camino que uniera $\mathrm{La} \mathrm{Pa}$ ciencia con Caleta María por el flanco norte del seno Almirantazgo es impracticable debido a lo escarpado de dicha ladera, toda en roca (...)

Parece impracticable también un camino que una Caleta María con la bahía Parry y desde este punto al valle Lapataia. Esta ruta sólo se observó precariamente y parcialmente.

47 Sólo a Garay y a Oyarzún se les paga, Reinaldo Catalán participa de forma voluntaria.

48 En la actualidad se han construido 4 de los $13 \mathrm{~km}$. que contempla el ramal Caleta María. 


\section{APENDICE II}

Cartas inéditas enviadas a Reinaldo Catalán en el transcurso de la expedición de 1978

Caleta María 4 de Marzo 1978

Señor

Reinaldo Catalán O.

Luis Arata C. Subof. de Ejército, integrante de esta comisión (amigo suyo ${ }^{49}$. Le solicita sus servicios para esta misión ya que es Ud. el único conocedor de estos lugares y sin Ud. sería imposible continuar con el trazado de este futuro camino.

Bueno don Cata lo esperamos acá para que conversemos los detalles. (económicamente le aseguro que irá bien)

Saludos Arata

Suboficial de Ejército

49

Luis Arata, en una ocasión previa a la expedición dirigida por Niemeyer en 1978 se extravió en la inmediaciones del cordón La Paciencia (tercio sur de Tierra del Fuego, Chile) mientras desarrollaba campaña de reconocimiento de la zona, en calidad de suboficial del ejército, en esa oportunidad Catalán y Oyarzún fueron vitales para el rescate ya que entregaron datos del sector en que deberían estar los militares extraviados. Desde ese momento y bajo esas circunstancias es que ya se conocía Catalán con Arata.
Caleta María 4 de marzo 1978

Señor

Reinaldo Catalán O.

Se encuentra en Caleta María comisión encargada por el gobierno de reconocer camino Vicuña a Yendegaia.

Se necesita para continuar de Caleta María al sur, alguien que conozca la ruta y la persona indicada es ud.

Por supuesto que esta labor que ud. ejecutará se le pagará conforme a lo que conversemos aquí en caleta.

Sabemos que ud. esta dispuesto a colaborar en esta importante misión que proporcionará un significativo adelanto a la zona, como es la construcción de este camino.

Le agradecemos trasladarse hasta Caleta María para conversar sobre este importante asunto. Cuando venga traiga en lo posible un caballo más. Lo esperamos

Saluda atte. a Ud.

Hans Niemeyer $f$.

Jefe Comisión Estudios 
